\title{
Tarpukario Vilniaus visuomeniniai pastatai: institucijų, funkcijų ir architektūros įvairovè ${ }^{1}$
}

\author{
Rasa Butvilaitè \\ Vilniaus dailès akademija \\ Maironio g. 6, LT-01124 Vilnius \\ rasa.butvilaite@vda.lt
}

Aneksuotame ir vaivadijos centro statusa igijusiame Vilniuje, kaip ir daugelyje kitų Lenkijos miestų, 1919-1939 m. steigèsi vietos valdžios, bankų, mokslo ir mokymo, sveikatos apsaugos, socialinio draudimo, komunikacijos bei transporto ir kultūros institucijos. Funkcinių programų ivairovè lèmė, kad to laikotarpio architektūros pavidalai buvo labai ịvairūs, susiklostė nevienalytės architektūros vaizdinys. Instituciniais sprendimais siekta apdairiai išsaugoti Vilniaus senamiesti, gaivinti jo paminklus, o nauji sumoderninto tradicionalizmo ir grynojo modernizmo pastatai išsyk anapus senojo miesto ribų (visų pirma Naujamiestyje) suteikè atsvarą carinio laikotarpio architektūriniam miesto vaizdiniui, brèžè naujas daugelio miesto teritorijų urbanistinès raidos ir architektūrinio peizažo gaires. Administracinei paskirčiai neretai buvo pritaikomi anksčiau statyti pastatai, o iškilę nauji architektūros kūriniai (ypač po 1935 m., kai valstybès ūkis ir ekonomika èmė atsigauti ir ị Vilnių plūstelëjo statybų banga) liudijo Antrosios Lenkijos Respublikos valdžios galių ir institucijų Vilniaus regione efektyvumą ir modernumą. Nemažai naujų visuomeninės architektūros projektų nespèta ịgyvendinti, jie taip ir liko brèžiniuose. Vis dèlto šių pastatų architektūra liudija pakankamai dinamišką stilistinę raidą ir kryptingas konceptualias projektuotojų paieškas siekiant surasti pastatų dermę su urbanistine ir kultūrine Vilniaus aplinka.

Reikšminiai žodžiai: Vilniaus architektūra, modernizmas, Varšuvos modernizmo mokykla, visuomeninè architektūra.

1 Straipsnis parengtas atliekant tyrimą „Vilniaus dailè ir architektūra 1919-1939 m.: institucinis aspektas“, finansuojamą Lietuvos mokslo tarybos pagal Nacionalinę mokslo programą „Modernybė Lietuvoje“ (sutarties Nr. S-MOD-17-12). 
1918 m. nepriklausomybę atkūrusioje Lenkijoje prasidejjo naujai besikuriančių administracinių struktūrų formavimo, Pirmojo pasaulinio karo padarinių likvidavimo ir kultūrinio bei ūkinio šalies modernizavimo procesai, kurie paskatino statybinę veiklą. Aneksuotame ir vaivadijos centro statusą igijusiame Vilniuje, kaip ir daugelyje kitų Lenkijos miestų, 1919-1939 m. steigèsi vietos valdžios, bankų, mokslo ir mokymo, sveikatos apsaugos, socialinio draudimo, komunikacijos bei transporto ir kultūros institucijos, sparčiai plètojosi gyvenamųjų namų ir rekreacinės paskirties objektų statyba. Atsikuriančios valstybės politiniai, sociokultūriniai, ūkiniai poreikiai ir galimybès tvèrè jų projekcijas architektūroje, institucionalizavo administracines Antrosios Lenkijos Respublikos galias naujai prijungtose teritorijose. Funkcinių programų ịvairovè lèmė, kad to laikotarpio architektūros pavidalai buvo labai ịvairūs, susiklostė nevienalytès architektūros vaizdinys.

Visuomeninės paskirties tarpukario Vilniaus architektūra kol kas nèra tyrinèta kompleksiškai ir nuodugniai, kaip ir visa aptariamojo laikotarpio Vilniaus architektūra, kuri, lyginant su Antrosios Lenkijos Respublikos didžiujų vaivadijų miestų (Varšuvos, Poznanès, Krokuvos, Legnicos, Vloclaveko, Gdynės) statybų tempais ir modernistinės raiškos užmojais, neretai laikoma menkaverte periferijos, nuo modernizmo centrų nutolusia kultūrinių „kresų“ apraiška. Tyrinėtojų dėmesys dažniausiai krypsta ị kelis ryškiausiais laikomus šio laikotarpio Vilniaus architektūros paminklus, kuriuos sukūrè Varšuvos modernizmo mokyklos atstovai². Naujausiuose ir kol kas išsamiausiuose tyrimuose, paremtuose daugiausia šaltiniais, architektūrologè Małgorzata Dolistowska apžvelgè Vilniaus architektūros raidos per tarpukario dvidešimtmeti tradicijų ir avangardo raiškos, varšuvietiškojo modernizmo ittaku klausimus ${ }^{3}$; mokslininkès straipsnyje pateiktas

2 Tarp svarbesnių galima paminėti: Edmund Małachowicz, „Architektura dwudziestolecia międzywojennego w Wilnie“, in: Studia i materiały do teorii i historii architektury i urbanistyki, t. XVII: Architektura i urbanistyka w Polsce w latach 1918-1978, Warszawa, 1989, p. 121-141; Józef Poklewski, Polskie życie artystyczne w międzywojennym Wilnie, Toruń: Wydawnictwo UMK, 1994, p. 170-196; Stefan Narębski (1892-1966) - architekt, konserwator, profesor: Katalog towarzyszy wystawie, autor katalogu Michał Pszczółkowski, Toruń: Muzeum Okręgowie w Toruniu, 2017; Vilnius, 1900-2016: architektūros gidas, sud. Marija Drèmaitė, Rūta Leitanaitė, Julija Reklaitė, Vilnius: Lapas, 2016; Michał Pszczółkowski, Architektura użyteczności publicznej II Rzeczypospolitej 1918-1939, Łódź: Dom Wydawniczy Księży Młyn, 2014; Idem, Kresy nowoczesne. Architektura na ziemiach wschodnich II Rzeczypospolitej 1921-1939, Łódź: Dom Wydawniczy Księży Młyn, 2016.

3 Małgorzata Dolistowska, ,,,Miłe miasto“ między tradycją a awangardą: architektura Wilna w dwudziestoleciu międzywojennym: zarys problematyki“, in: Stan badań nad wielokulturowym dziedzictwem dawnej Rzeczypospolitej, t. 8, Białystok: Instytut Badań nad Dziedzictwem Kulturowym Europy, 2017, p. 87-149. 
mozaikiškas tarpukario Vilniaus architektūros stilinės raidos vaizdas, nefokusuojantis dėmesio ị tipologinius aspektus.

Priminsiu, bet šiame straipsnyje nenagrinèsiu bemaž ikoniniais tapusių tarpukario Vilniaus modernizmo ,inkliuzų“ Gedimino prospekte, kurie suteikè modernistinę atsvarą iki tol carinès Rusijos imperijos laikais kurtos istorizmo stilistikos visuomeninès reprezentacinès paskirties formoms ir brèžè naujo, atgimusiai Lenkijai priklausiusio miesto tapatybę. Pradžią davė Brolių Jabłkowskių prekybos namai Gedimino prospekte (Dom Towarowy Braci Jabłkowskich, archit. Kazimierzas Krzyżanowskis, Karolis Jankowskis, Franciszekas Lilpopas, 1919). Kitas naujos architektūros objektas - 1931 m. Varšuvos politechnikos atstovų Zygmunto Tarasino ir Stefano Bohusz-Siestrzencewicziaus suprojektuoti modernizuoto tradicionalizmo Prekybos ir amatų rūmai (Gedimino pr. 36, dab. Konstitucinio teismo rūmai). Svarbiausiomis modernaus miesto dvasios raiškomis tapo trys gerai žinomi socialinès bei komercinės-bankinės paskirties objektai, čia atsiradę 1936-1938 m. dèl pažangių užsakovų ir Lenkijos architektų sajungos organizuotų konkursų Juos laimėję žinomi Varšuvos modernizmo architektūros grandai, padedami vietos architekto Jano Borowskio, derinosi prie Vilniaus architektūros mastelio ir reprezentatyvaus, paminklinio sostinès statuso. Pašto taupomosios kasos rūmai su prišlietu gyvenamojo namo korpusu (archit. Zbigniewas $\mathrm{Pu}-$ getas, Juliuszas Żórawskis, 1936-1937, Gedimino pr. 12, dab. SEB bankas), kurių asketiškoms funkcionalizmui būdingoms formoms reprezentatyvumo bei prabangos suteikia kokybiška gelsvo smiltainio ir granito plokščiu apdaila - savotiškas polinkis ị dekoratyvumą ir fasadiškumą, siunčiantis žinią apie valstybinès institucijos tvarumą ir galią. Greta šių rūmų komplekso pastatytas Lenkijos krašto ūkio bankas (archit. Stanisławas Galęziowskis, Jerzis Pankowskis, 1937-1938, Gedimino pr. 14) - tai savita Le Corbusier šveicaru studentų rezidencijos Paryžiuje (1930-1932) interpretacija, ypač akivaizdi laiptinès rizalito, paremto ant atraminių stulpų, motyve. Nuo gatvės atitrauktas pastatas ir priešais ji suformuota aikštè (joje planuota statyti Adomo Mickevičiaus paminklą) akivaizdžiai „lauže“ XIX a. pabaigoje - XX a. pradžioje carinès imperijos laikais pradètą formuoti banalų perimetrinị prospekto užstatymą ir suteikè jam gyvybingo dinamiškumo. Naujos, „lenkiškosios“, 
tapatybės suteikimą ir modernizavimą tuometiniam A. Mickevičiaus prospektui ženklino ir Visuomeninio draudimo bendrovès rūmai (archit. Stanisławas Murczyńskis, Jerzis Soltanas, 1938-1938, Gedimino pr. 27). Mokykla Liepkalnyje, 1939 m. iškilusi pagal žymaus Varšuvos modernisto Romualdo Gutto ir jo asistentu Vilniaus urbanistikos biure dirbusio inžinieriaus architekto Stanisławo Bukowskio ${ }^{5}$ projektą, buvo bemaž ryškiausias modernistinės architektūros štrichas ir naujoviškos švietimo sistemos įkūnijimo architektūroje pavyzdys lyg ir netikètoje - periferinèje - Vilniaus dalyje. Šie pastatai išties brèžè naują tiek miesto centrinès dalies, tiek atokesnių teritorijų urbanistinès raidos ir architektūrinio peizažo viziją ir gaires, formavo Vilniaus kaip modernaus atsikūrusios valstybès miesto vaizdinị. Vis dèlto aptariamojo laikotarpio statybinès veiklos palikimas gerokai gausesnis, kokybiniu bei funkciniu požiūriu ìvairesnis ir nesitelkia vien centrinejje Naujamiesčio ašyje.

Nauji tyrimai atskleidžia pakankamai sudètingą ir ịvairialypę tarpukario dvidešimtmečio institucijų Vilniuje kūrimosi ir jų architektūrinio ìvaizdinimo panoramą. Šiame straipsnyje, nepretenduojančiame į išsamų ir baigtinį tyrimą, mėginama identifikuoti ir apžvelgti mažiau žinomus ar visai nepastebimus, marginalinius ar nerealizuotus architektūrinius projektus, taip pat labai specifinès paskirties visuomeninès architektūros objektus, kurie liudija iki šiol menkai pažintą institucinę aptariamojo laikotarpio Vilniaus architektūros funkcijų ịvairovę, atliepiančią daugialypius socialinius, ūkinius ir kultūrinius tuometinès valstybès statybų politikos tikslus.

Kuriantis valstybei ir jos institucijoms, administracinei paskirčiai neretai buvo pritaikomi anksčiau statyti pastatai. Vienas ankstyviausiu tokio pritaikymo ir su juo susijusio perprojektavimo pavyzdys - tai Vilniaus mokyklų apygardos kuratorijos (Kuratorjum Okręgu Szkolnego Wileńskiego) ịkurdinimas buvusių Universiteto klinikų, chemijos laboratorijos ir medicinos kolegijos pastatuose pagal Stepono Batoro universiteto architektūros profesoriaus Juliuszo Kłoso 1924 m. projektą. Reprezentacinị naujos pastato funkcijos aspektą vainikavo Ovaliosios salès ịrengimas':

5 Sebastian Wicher, Żyć architekturą. Życie i twórczość Stanistawa Bukowskiego (19041979), Białystok: Stowarzyszenie Architektów Polskich Oddział w Białymstoku, Studio Wydawnicze UNIKAT, 2009, p. 17-18.

6 Vilniaus švietimo apygardos kuratorijos (dab. Švietimo, mokslo ir sporto ministerija) ovaliosios salès rekonstrukcijos ir dekoro projektas, archit. Juliuszas Klosas, 1924, in: VDAM, A-248. Publikuotas: (Ne)matomas Vilnius: tarpukario dailès ir architektūros pavidalai: Parodos Vytauto Kasiulio dailès muziejuje (2018 0612 - 201809 16) katalogas, sudarytojos ir tekstų autorès Algė Andriulytè, Rasa Butvilaitè, Ilona Mažeikienè, Vilnius: Vilniaus dailès akademijos leidykla, 2018, p. 14. 


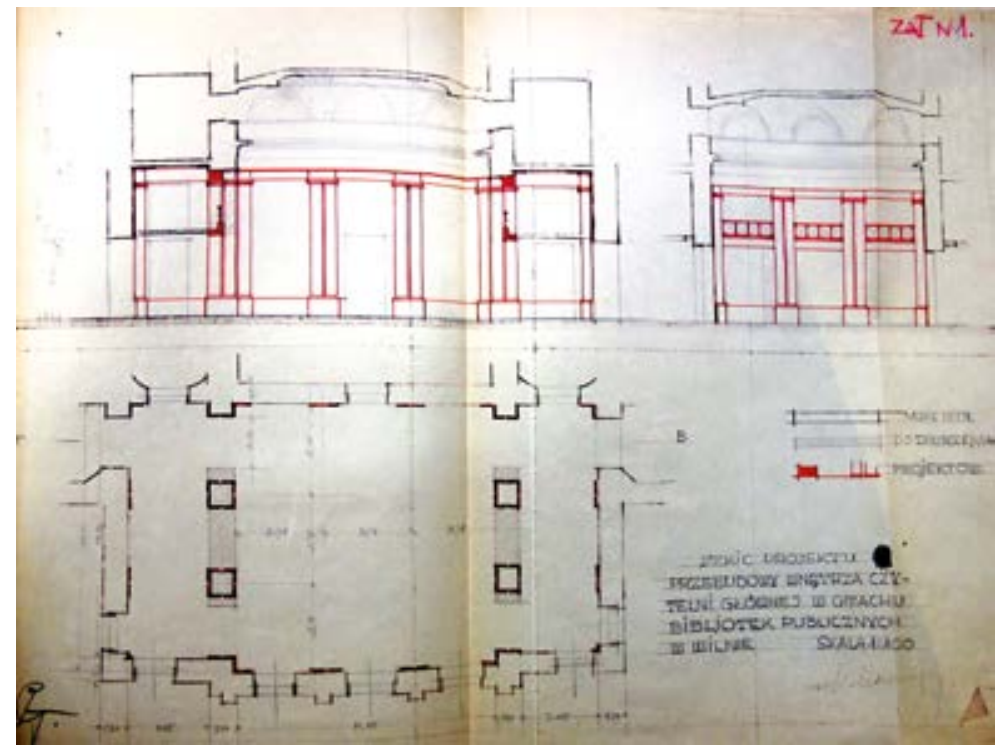

1.

Tiškevičių rūmų Vilniuje pritaikymo Valstybinei Vrublevskių bibliotekai projektas: skaitykla, archit. Stanisławas Jerzis Miecznikowskis, 1926-1931, AAN
Project for the adaptation of Tyszkiewicz' Palace in Vilnius to the Wrublewski State Library: reading room

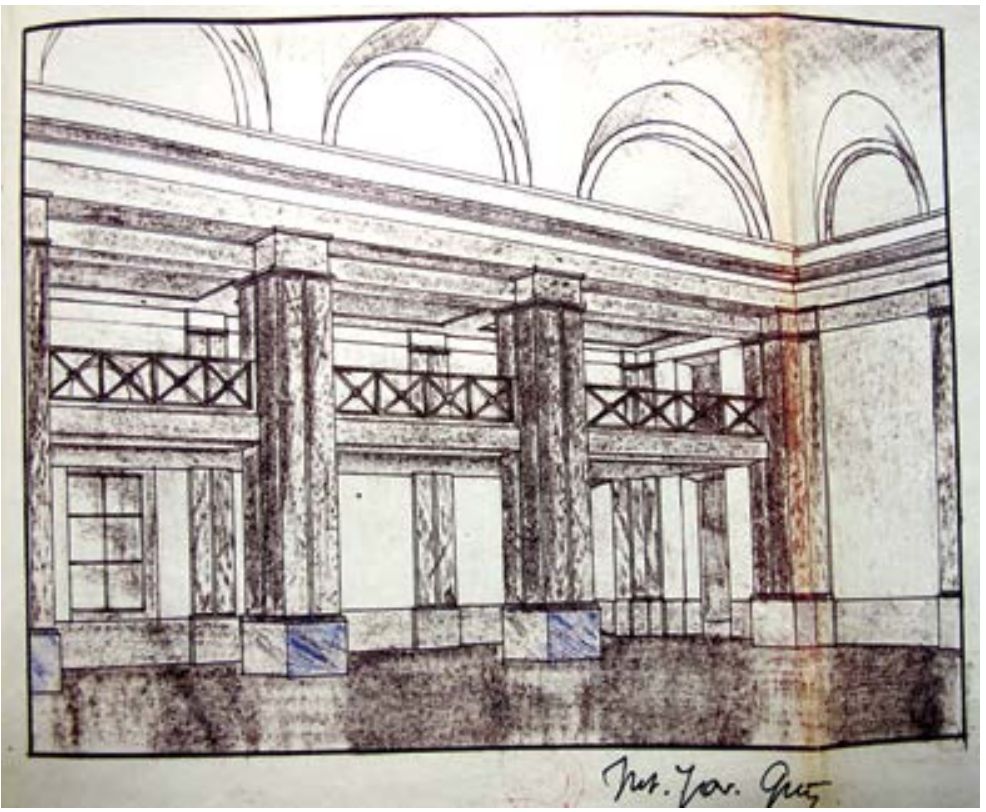

2.

Tiškevičių rūmų Vilniuje pritaikymo Valstybinei Vrublevskių bibliotekai projektas: skaitykla, archit. Stanisławas Jerzis Miecznikowskis, 1926-1931, AAN
Project of adaptation of Tyszkiewicz' Palace in Vilnius to the Wrublewski State Library: reading room 
jai suteiktas retrospektyvus neoklasicistinis ịvaizdis (kesonus imituojantis skliautas, baltų koklių krosnys arkinėse nišose, toskaniškosiosios kolonos, laikančios galeriją), subtiliai atgaivinantis architekto Mykolo Šulco 1809$1910 \mathrm{~m}$. sukurtą senojo universiteto kolegijos dvasią.

Tarpukariu romantizuojamą Vilniaus, kaip Lietuvos Didžiosios Kunigaikštystès sostinès ir savivaldą puoselèjusio miesto, garbingą tradiciją siekta ịprasminti rotušeje įkuriant miesto muziejų ir reprezentacinę salę. Pirmuosius tyrimus ir pritaikymo Valstybiniam Vilniaus muziejui pasiūlymus 1924 m. parengė architektas Juliuszas Kłosas, 1928 m. Vilniaus miesto vyriausiasis architektas Stefanas Narębskis parengė kitą Rotušès pertvarkymo ir pritaikymo projektą. Projekte sumanymas atkurti sunaikintą Lauryno Gucevičiaus suplanavimą bei interjero vaizdą derintas su pritaikymu modernioms reikmėms ${ }^{7}$. Iš esmès tai buvo pirmasis dideliu sutelktinių architektų, konservatorių (restauratorių) bei dailininkų pastangų ir konceptualių apsisprendimų reikalavęs reikšmingo paveldo objekto senamiesčio teritorijoje tvarkybos projektas (darbai pradèti tik 1936 m.), atskleidęs tuo metu Vilniaus aplinkoje subrendusias požiūrio ị paveldą sampratas, gristas nuodugniais tyrinejjimais.

Visuomeninių objektų projektus valstybės vykdomosios valdžios ar Vilniaus vaivadijos administracijos nurodymu daugiausia inicijavo, rengè ir vykdymą prižiūrẻjo šios vaivadijos valdybos Viešujų darbų direkcijos Konstravimo biuras (Biuro Konstrukcyjne przy Wilenskim urządzie wojewodskim, Okręgowej dyrekcji robot publicznych), vèliau, po Vilniaus vaivadijos administracinės pertvarkos, - šios valdybos Komunikacijos ir statybos skyrius (Wydział Kominikacyjno-Budowlany). Mažai žinomas (bet gerai visiems pažistamas) ir vienas pirmuju pastato konversijos Vilniuje atvejų - tai Tiškevičių rūmų pritaikymas Valstybinei Vrublevskių bibliotekai, vykęs 1926-1931 m. (valstybè pastatus išpirko iš Tiškevičių) ${ }^{8}$. Projekto autorius - architektas Stanisławas Jerzis Miecznikowskis (1887-1951), Rygos politechnikos absolventas (1914), gyvenęs ir miręs Gdynëje. Pritaikant naujai paskirčiai, laikytasi nuosaikios neotradicionalistinès modernizmo krypties, erdvès modernizuotos (irrengti nauji pagalbiniai laiptai, saugyklos

7 Ibid., p. 16-21.

8 Sprawa biblioteki im. Wróblewskich w Wilnie, 1931 r., in: AAN, z. 9: Ministerstwo Spraw Wewnętrznych, sygn. 3815; Projekt przebudowy Pałacu poTyszkiewiczowskiego w Wilnie na gmach bibliotek publicznych, 1928, in: AAN, z. 9: Ministerstwo Spraw Wewnętrznych, sygn. 3816. 

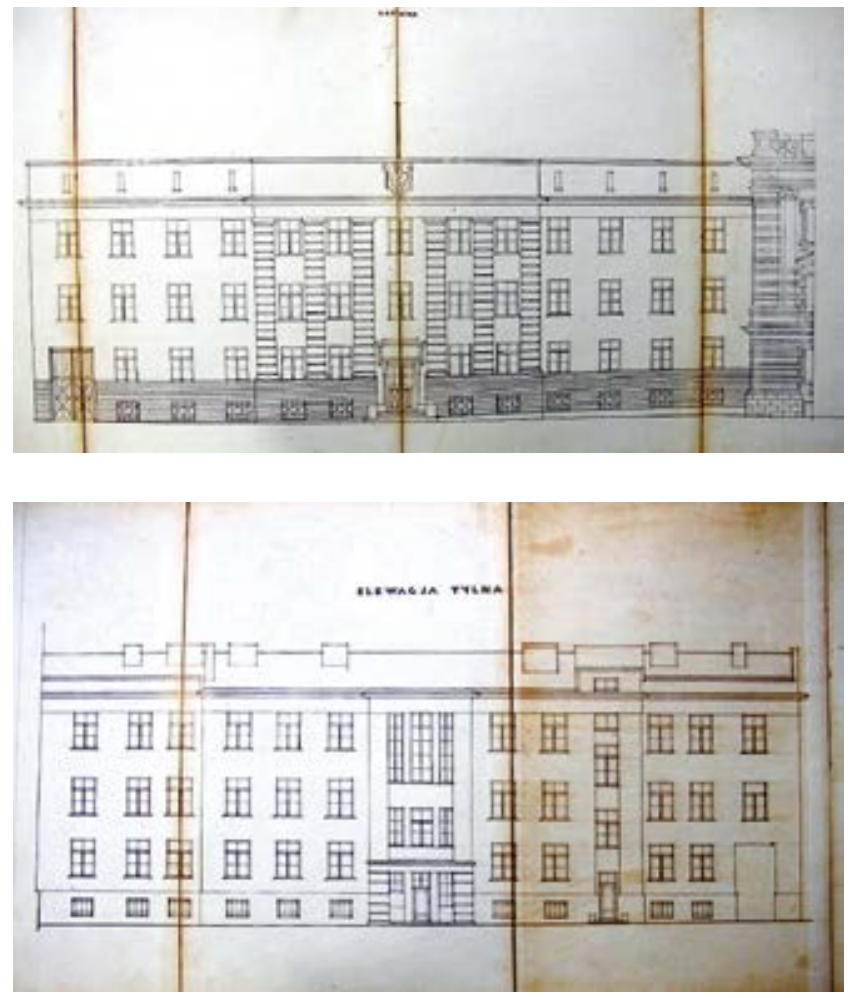

3.

Miesto teismo rūmai

(dab. Lietuvos

apeliacinis teismas)

Vasario 16-osios g.:

pagrindinis fasadas,

archit. Jerzis Paprockis, 1928-1930, AAN

City Court (now the Lithuanian Court of Appeal) at Vasario 16-osios St: front façade

\author{
4. \\ Miesto teismo rūmai \\ (dab. Lietuvos \\ apeliacinis teismas) \\ Vasario 16-osios g.: \\ galinis fasadas, archit. \\ Jerzis Paprockis, \\ 1928-1930, AAN \\ City Court (now the \\ Lithuanian Court of \\ Appeal) at Vasario \\ 16-osios St: back façade
}

ir skaityklos) subtiliai išlaikant buvusių rūmų sandarą [1, 2 il.]. Šios konversijos rezultatai mažai pakitę išliko iki mūsų dienų.

Daug diskusijų to meto visuomenèje sulaukè Vilniaus miesto teismo rūmų (Vasario 16-osios g.) korpusas, pagal Varšuvos politechnikos absolvento (1924), po studiju paskirto dirbti Vilniaus vaivadijos valdyboje, Jerzio Klemenso Paprockio (1895-1962) projektą 1928-1929 m. prišlietas prie buvusių gubernijos teismo rūmų (jie pastatyti $1893 \mathrm{~m}$. pagal Peterburgo architekto Vasilijaus Prusakovo projektą) ${ }^{10}[3,4$ il.]. Lyginant su impozantišku neorenesansinės stilistikos imperiniu pastatu, naujasis priestatas buvo mažesnio tūrio ir supaprastinto klasicizmo formų. Projektas sulaukè audringos amžininkų kritikos dèl architektūrinio disonanso ir „,blankumo“ lyginant su cariniu pirmtaku, bet priekaištus iš dalies atrėmè vaivadijos

9 Projekt Sądu Grodzkiego w Wilnie, archit. Jerzy Paprocki, 1928, in: LCVA, f. 51, ap. 10, b. 1300 .

10 Nijolè Lukšionytè-Tolvaišienė, Istorizmas ir modernas Vilniaus architektūroje:

Monografija, in: Acta Academiae Artium Vilnensis, t. 18, Vilnius: Vilniaus dailès akademijos leidykla, 2000 , p. 42. 


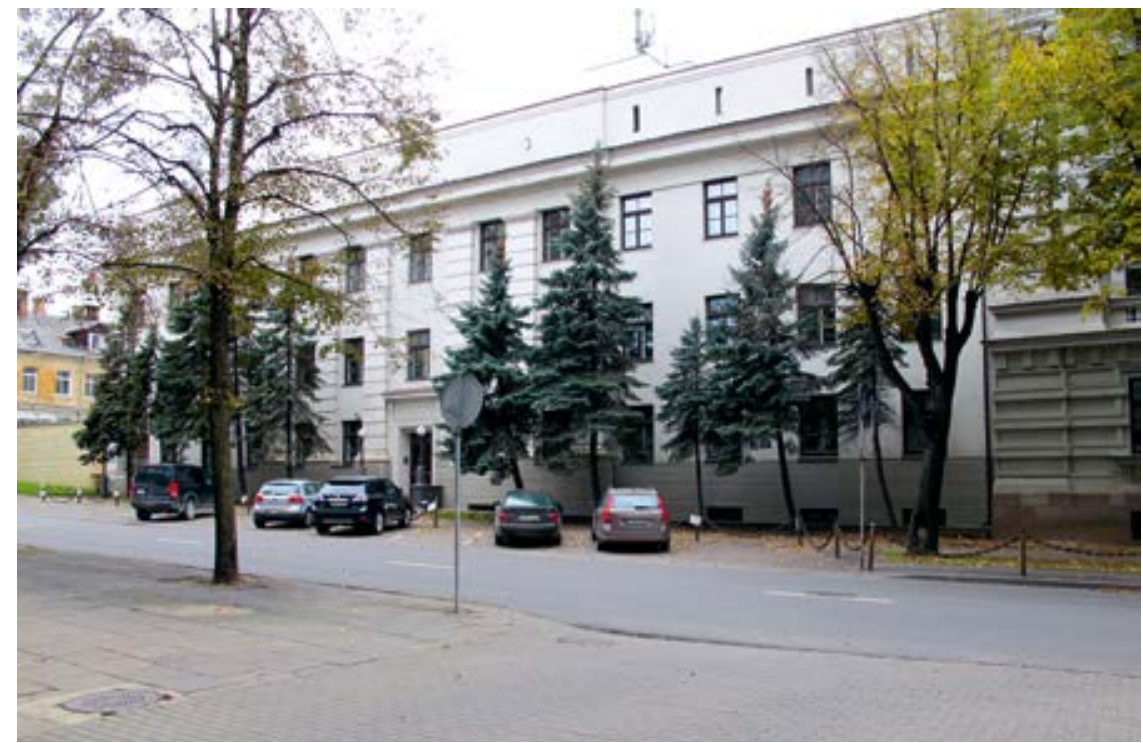

5.

Miesto teismo rūmai (dab. Lietuvos apeliacinis teismas) Vasario 16-osios g.: pagrindinis fasadas, Rasos Butvilaitès nuotrauka, 2020
City Court (now the Lithuanian Court of Appeal) at Vasario 16-osios St: front façade

Statybos taryba, kurią sudare Stepono Batoro universiteto Menų fakulteto atstovai, miesto architektas ir vyriausiasis paminklų konservatorius. Tačiau ir ši Taryba pateikẻ išvadą dèl tokios architektūros praktikos ateities:

negalima sekti architektūrinio skonio nuosmukio laikotarpio rusiška architektūra $<\ldots>$, kurioje turginiai pagražinimai $<\ldots>$ užgožia architektūrinès kompozicijos mintį. ${ }^{11}$

Nauja pastato dalis peikta dèl „,baisingos priestato, prilipdyto dideliu tempu prie Teismo pastato, disproporcijos“, stebètasi, kodèl „nei konservatoriaus tarnyba, nei miesto architektas ị tai nereaguoja“"12, ironizuota, kad tai „pakenčiamas mėginimas paviršutiniškai sueuropinti Kalugos tradicijas, pasitelkiant visiškai nesubtilias menines priemones ir labai dideles lëšas "“13 [5 il.]. Viešujų darbų direkcijos Konstrukcijų biure (Biuro Konstrukcyjne

11 Akta w sprawie budwy Sądu Grodzkiego w Wilnie, 1929-1929, in: LCVA, f. 51, ap. 10, b. 1296 (lapai nenumeruoti).

12 „Rządowa tandeta budowlana“, in: Dziennik Wilenski, 192924 (VI).

13 LCVA, f. 51, ap. 10, b. 1296 (lapai nenumeruoti). 
Dyrekcji Robót Publicznych w Wilnie) parengtas projektas išties siekė nedisonuoti su senesnio pastato architektūra ir sykiu komunikuoti to laiko dvasią, tačiau sukilusi opozicijos banga akivaizdžiai paliudija požiūrị ị carinès imperijos laikotarpio architektūros sluoksnị miesto audinyje.

Nepaisant ekonominės krizès, kurią XX a. 3 deš. išgyveno Lenkija, imta gausiai statyti įvairių valdybų administracinius pastatus, kuriuose veikè aukščiausių valdžios institucijų (Aukščiausiosios kontrolès rūmų, Bedarbystès ir Darbo fondų, Valstybinių miškų ir Valstybinių geležinkelių direkcijų, Žemès ūkio valdybos ir kt.) vykdomieji padaliniai vaivadijose. Jie projektuoti pagal pakankamai vieningą nusistovėjusią funkcinę plano schemą: dažniausiai ištęsto stačiakampio plano su pagrindiniu iejjimu centriniame rizalite, holu ir laiptine iẹjimo ašyje, susirinkimų sale pirmo aukšto centre ir vadovybès kabinetais abipus, kitoje aukšto pusèje - darbuotojų kabinetai (kanceliarija, sekretoriatas, referentų darbo vietos ir pan.). Pastatų viršutiniuose aukštuose ar atskiruose priestatuose - gyvenamosios aukščiausio rango tarnautoju patalpos. Tokių žinybinių ịstaigu statybos buvo numatytos ir Vilniuje. Kai kurias svarbiausias valstybines institucijas skubèta steigti, laiko ir lèšų jų statyboms nebuvo, todèl, nepaisant negatyvios išankstinès nuostatos, vietos joms ieškota po nepriklausomybės atkūrimo atsilaisvinusiuose ankstesnès valdžios pastatuose. Antai Aukščiausiujų kontrolès rūmų ${ }^{14}$ (t. y. mokesčių kontrolès institucija) Vilniaus padaliniui nebuvo rengiamas naujas projektas - istaiga, nepaisant negatyvaus carinio laikotarpio architektūros įvaizdžio, suskubta ikurti tuometinèje A. Mickevičiaus gatvėje (dab. Gedimino pr.) buvusiuose Valstybinio banko rūmuose - bene ištaigingiausiame iš visų iki Pirmojo pasaulinio karo Vilniuje statytų bankų (archit. Michailas Prozorovas, 1905).

XX a. 3 deš. viduryje ketinta statyti $1924 \mathrm{~m}$. prezidento potvarkiu ìsteigtos Valstybinès mišku direkcijos (Dyrekcja Lasow Panstwowych) ${ }^{15}$

$141919 \mathrm{~m}$. valstybès vadovo dekretu buvo patvirtinti Aukščiausieji valstybès kontrolès rūmai (Najwyższa Izba Kontroli Państwa, vèliau pervadinti į Najwyższa Izba Kontroli), kurie turèjo visapusiškai kontroliuoti valstybès ir visuomenės finansus; Dekret o najwyższej Izbie Kontroli Państwa, Dziennik Ustaw, 1919, Nr. 14, poz. 183, [interaktyvus], [žiūrèta 2020-01-12], http://isap.sejm. gov.pl/isap.nsf/DocDetails.xsp?id=WDU19190140183. $1921 \mathrm{~m}$. priimtas nutarimas ịkurti regioninius padalinius (Izba Okręowa Konroli) Varšuvoje, Lvove, Kielcuose, Kovle, Poznanėje ir Vilniuje; Ustawa z dnia 3 czerwca 1921 r. o Kontroli Państwowej, Dziennik Ustaw, 1921, Nr. 51, poz. 314, [interaktyvus], [žiūrèta 2020-02-04], http://isap.sejm.gov.pl/isap.nsf/DocDetails.xsp?id=WDU19210510314; Utworzenie okręgowej izby Kontroli Państwowej w Wilnie, 1922, Dziennik Ustaw, Nr. 51, poz. 314, [interaktyvus], [žiūrèta 2020-01-11], https:/www.prawo.pl/akty/dz-u-1922-75-684,16879789.html.

15 Rozporządzenie Prezydenta Rzeczypospolitej z dnia 28 czerwca 1924 r. o statucie przedsiębiorstwa „Polskie Lasy Państwowe“, Dz. U. z 1924 r., Nr. 56, poz. 570, [interaktyvus], [žiūrèta 2020-01-14], http://isap.sejm.gov.pl/isap.nsf/DocDetails.xsp?id=WDU19240560570. 


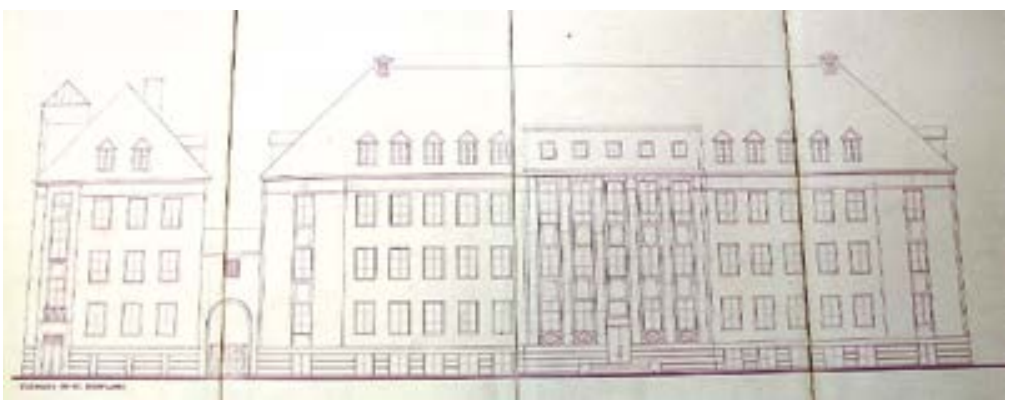

Valstybinès miškų direkcijos pastatụ komplekso J. Basanavičiaus g. projektas: pagrindinis administracinio korpuso fasadas, archit. Jerzis Beillis, 1926, AAN
Project of the building complex of the State Forest Directorate at J. Basanavičiaus Str: the front façade of the administrative building
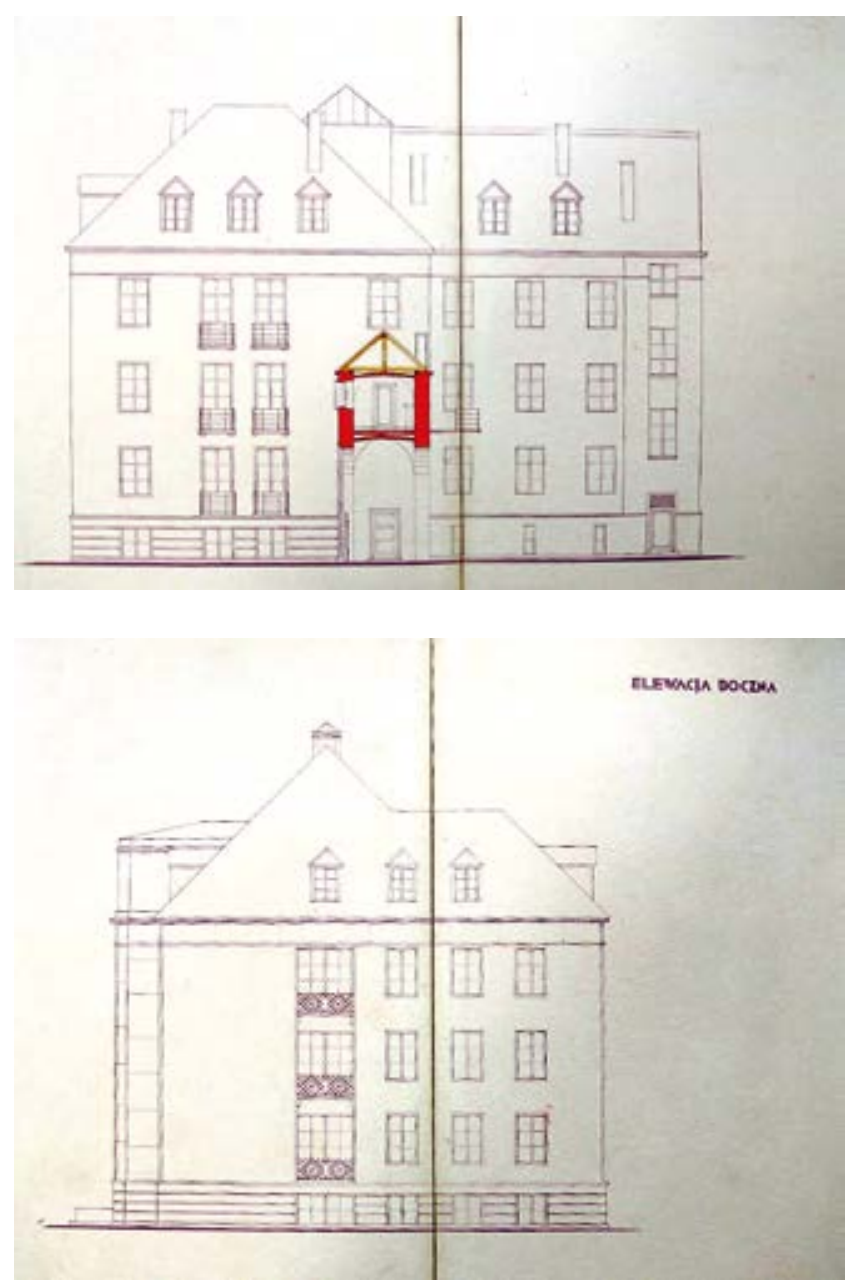

7.

Valstybinès

miškų direkcijos pastatų komplekso

J. Basanavičiaus g. projektas: pagrindinis gyvenamojo korpuso fasadas, archit. Jerzis Beillis, 1926, AAN

Project of the building complex of the State Forest Directorate at J. Basanavičiaus Str: the front façade of the residential building

8.

Valstybinès miškų direkcijos pastatų komplekso J. Basanavičiaus g. projektas: šoninis administracinio korpuso fasadas, archit. Jerzis Beillis, 1926, AAN

Project of the building complex of the State Forest Directorate at J. Basanavičiaus Str: the side façade of the administrative building 
pastatų kompleksą Basanavičiaus gatvèje. Išlikę du nerealizuoti projektai ${ }^{16}$, skirti šiai Vilniaus vaivadijai strategiškai itin svarbiai institucijai, - miškininkystė buvo viena iš prioritetinių regiono pramonès šakų ir didžiausias ekonomikos ramstis. Pirmajj projektą $1926 \mathrm{~m}$. parengè Gdansko politechnikos absolventas, architektas inžinierius ir urbanistas Jerzis Beillis (1885-1876), tuo metu ejjęs aukštas pareigas keliose statybas kuravusiose ministerijose Varšuvoje (Vidaus reikalų, Viešujų darbų, Miestų ir gyvenviečių statybos). Jo sumanymu, pastatas turëjo būti monumentalaus tūrio, visi elementai komponuoti taip, kad pabrèžtų jo vertikalumą: triaukštis su cokoliu, su aukštu šlaitiniu stogu (čia planuota ịrengti pastogę su langais), portiku ir lizenomis pabrēžtu pagrindiniu įejjimu, fasaduose - siauroki aukšti langai; įstaigą su gyvenamuoju korpusu jungia didinga įejjimo arka-vartai - tarpukariu Vilniuje labai mėgtas komplekso daliu jungimo būdas [6-8 il.]. Pastate buvo kompaktiškai ir racionaliai suplanuota funkcinè erdvių sąranga: abipus pirmo aukšto koridoriaus buvo ịrengti atskiri kabinetai direktoriui, jo pavaduotojui, sekretoriui, sąskaitininkui, teisininku ir personalo skyriams, inspektoriams, viršininkui, laukiamajam, tualetams; cokoliniame aukšte ikkurdintos muziejaus ir bibliotekos salės, viršutiniame - konferencijų salè, o palëpèje - žemėlapių ir matavimo prietaisų saugykla. Kitas, vėlesnis, minèto J. Paprockio projektas (1930) - jau gerokai modernesnis ${ }^{17}$. Pastatas keturių aukštų, lèkštu stogu, taip pat simetriškas, bet pagrindinị i̇ejjimą išryškina ne orderinès architektūros interpretacija, o langu kompozicija ir tarp jų ịkomponuota bei cokoli dengianti dekoratyvinė apdaila. Institucijos pastatas buvo sujungtas pereinamuoju dviaukščiu priestatu virš ịvažiavimo ị kiemą angos (vartų) su palyginti nekukliai dideliu gyvenamuoju direktoriaus šeimai skirtu korpusu - jo architektūra daug modernesnè, neturi pabrèžtinai reprezentacinio „patoso“ [9-11 il.]. Šis projektas taip ir nebuvo igyvendintas - Direkcija ịsikūrè viename iš senamiesčio pastatų (Didžioji g. 66).

$1924 \mathrm{~m}$. Lenkijoje įkurtas Bedarbystės fondas, privalèjęs teikti paramą neturintiems darbo ir gyvenantiems sunkiomis buities sąlygomis; $1933 \mathrm{~m}$. ịsteigtas ir Darbo fondas, kurio misija buvo padèti surasti darbą arba pragyvenimo šaltinį (pvz., atlikti bent viešuosius, visuomenei naudingus

16 Projekt gmachu dyrekcji Lasów Państwowych w Wilnie, in: AAN, z. 9: Ministerstwo Spraw Wewnętrznych, sygn. 3817; Projekt gmachu dyrekcji Lasów Państwowych w Wilnie, 1930 r., in: LCVA, f. 51, ap. 10, b. 1301.

17 Ibid. 


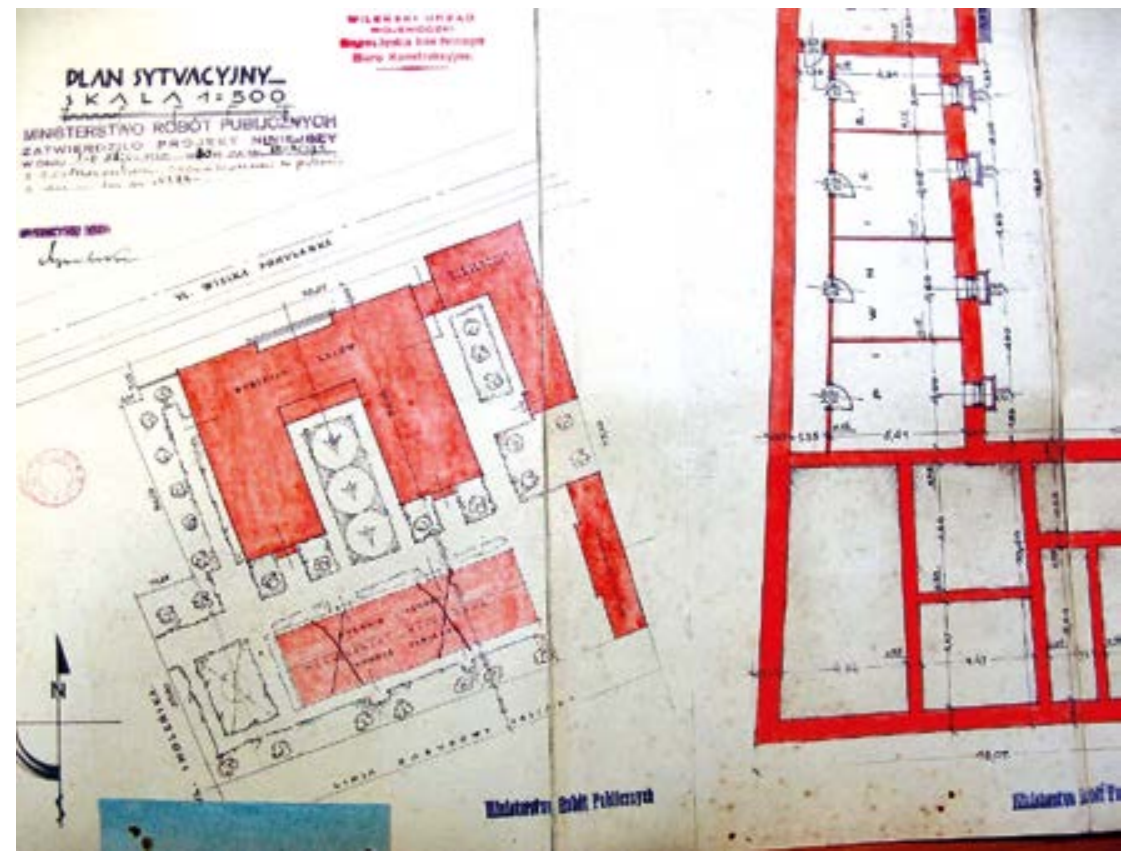

9.

Valstybinès miškų direkcijos pastatų komplekso J. Basanavičiaus g. projektas: situacijos planas, archit. Jerzis Paprockis, 1930, LCVA
Project of the building complex of the State Forest Directorate at J. Basanavičiaus Str: situation plan

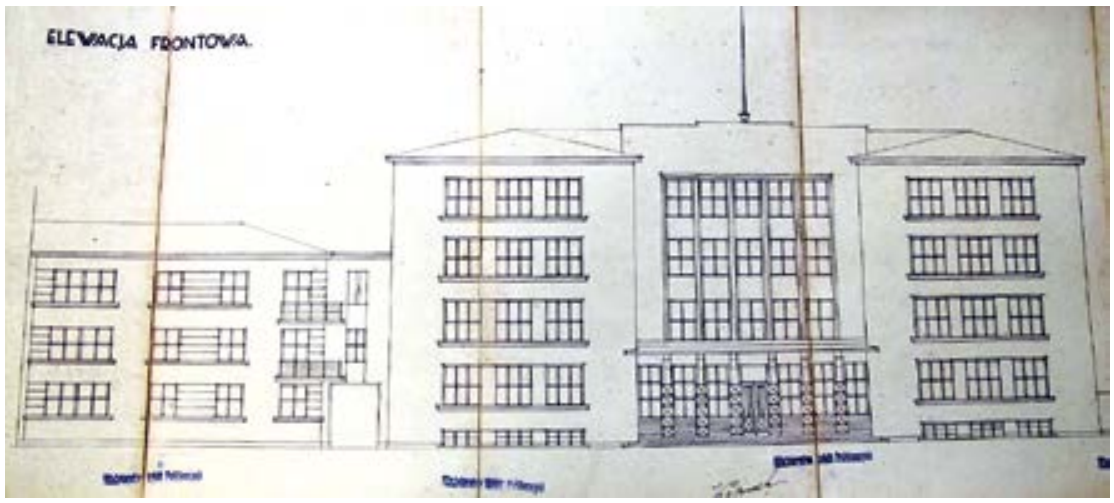

10.

Valstybinès miškų direkcijos pastatų komplekso J. Basanavičiaus g. projektas: pagrindinis fasadas, archit. Jerzis Paprockis, 1930, LCVA
Project of the building complex of the State Forest Directorate at J. Basanavičiaus Str: the front façade 


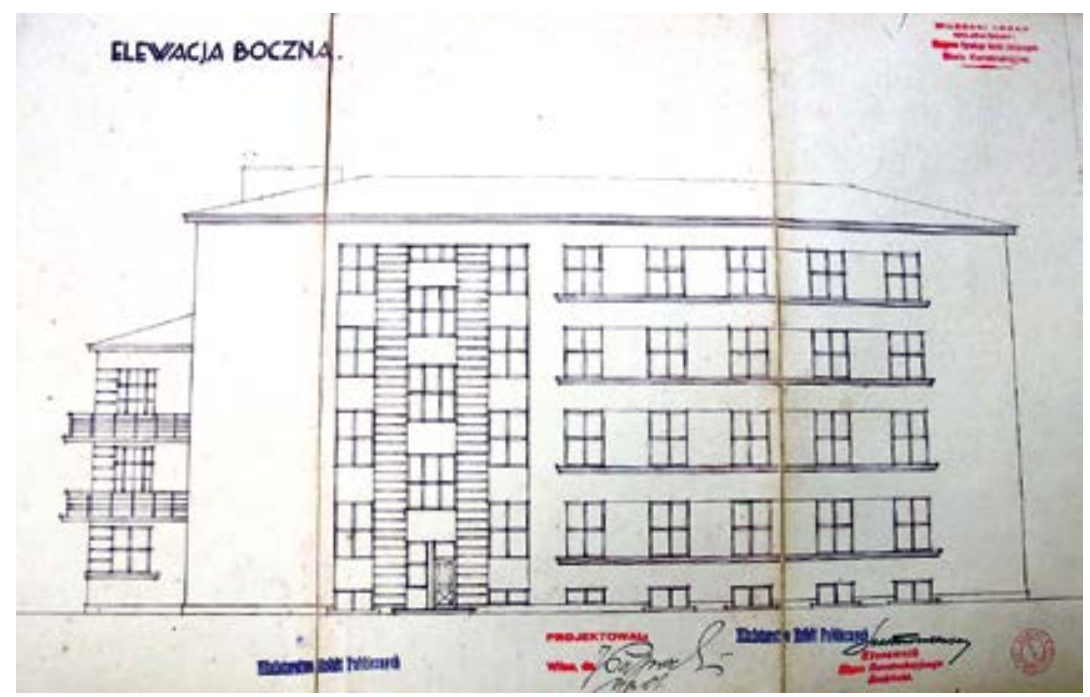

11.

Valstybinès miškų direkcijos pastatų komplekso J. Basanavičiaus g. projektas: šoninis fasadas, archit. Jerzis Paprockis, 1930, LCVA
Project of the building complex of the State Forest Directorate at J. Basanavičiaus Str: the side façade

darbus) žmonėms, neturintiems darbo ${ }^{18}$. Valstybė buvo numačiusi investuoti i šių institucijų atstovybių - Bedarbystès fondo pastatų, vadintų darbo rinkos būstinèmis (Giełda pracy), statybas Poznanėje, Krokuvoje, Torunėje, Katovicuose ir Vilniuje. Šios paskirties objektams būdingas savitas erdvių planavimas. Svarbiausia pirmo aukšto patalpa - tai didelè salè, padalyta i moteru ir vyrų skyrius, kuriuose teikta informacija apie darbo pasiūlymus ir derètasi su potencialiais darbdaviais. Šitai buvo numatyta ir $1930 \mathrm{~m}$. to paties Vilniaus vaivadijos valdybos Komunikacijos ir statybos skyriaus architekto J. Paprockio suprojektuotos Darbo rinkos būstinès ${ }^{19}$ (Šv. Dvasios g.) pastate [12 il.]. Savitas jo elementas - atskira dalis (patalpa), skirta inteligentijai, liudija ryškų socialinị susisluoksniavimą tarpukario Vilniuje: pastato funkcinị zonavimą apsprendè ne tik laikmečiui būdinga diferenciacija lyties, bet ir visuomenės sluoksnių požiūriu. Šiame aukšte taip buvo numatytas viršininko kabinetas, rūkomasis, tualetai, greta ịejimo - policijos posto patalpa. Antrame aukšte - rūbinè, svečių kambarys ir viršininko butas. Modernios paskirties būstinè - tradicionalistinių formų: stačiakampio

18 Ustawa z dnia 16 marca 1933 r. o Funduszu Pracy, Dz. U. 1933, Nr. 22, poz. 163, [interaktyvus], [žiūrèta 2020-02-01], http://isap.sejm.gov.pl/isap.nsf/DocDetails.xsp?id=WDU19330220163.

19 Projekt gmachu Giełdy pracy, 1930 r., in: LCVA, f. 51, ap. 10, b. 1316; Ibid., AAN, z. 9: Akta Ministerstwa Spraw Wewnętrznych, sygn. 3821. 

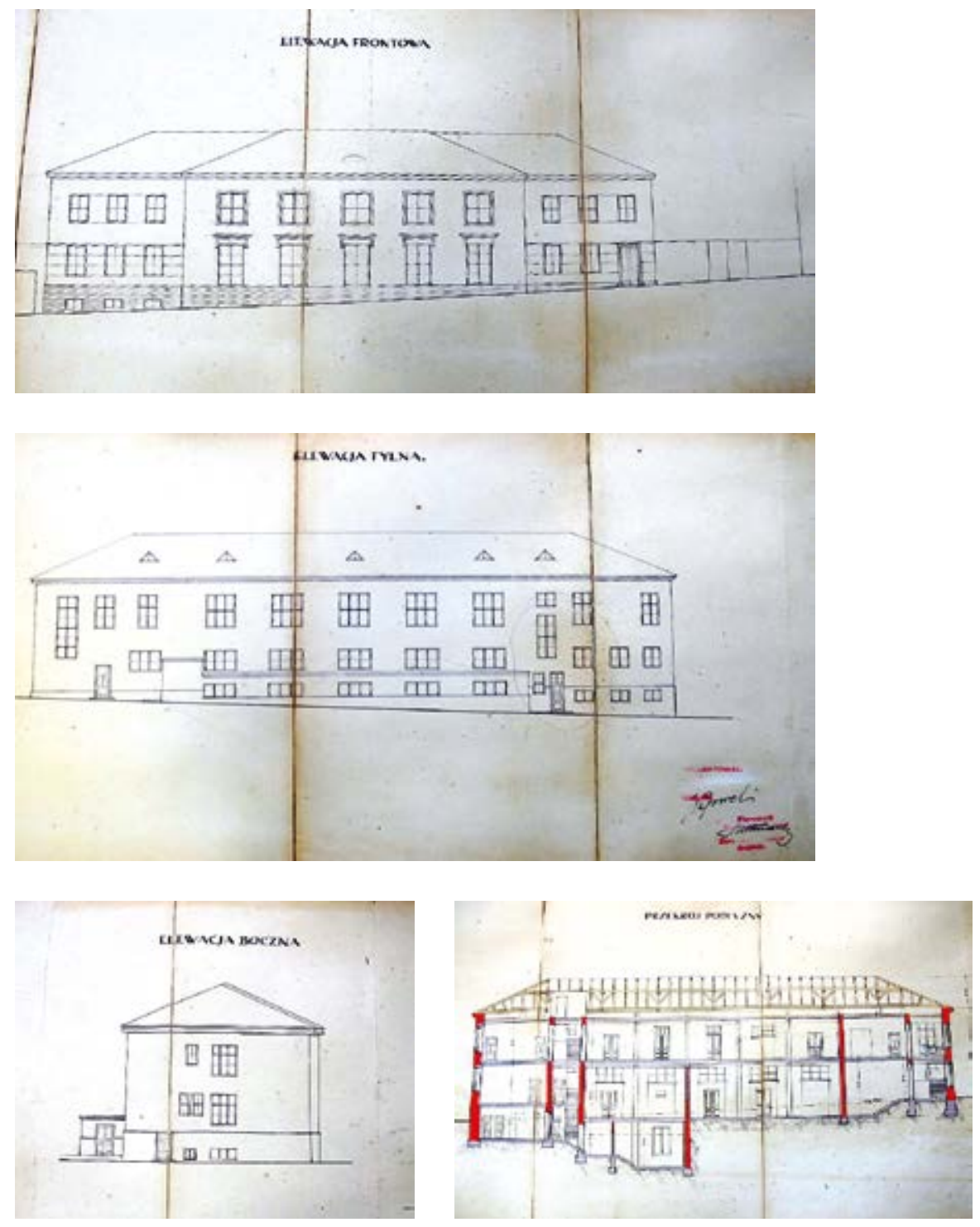

12.

Darbo rinkos pastato Šv. Dvasios g. projektas: pagrindinis, šoninis ir galinis fasadai, skersinis pjūvis, archit. Jerzis Paprockis, 1930, AAN

Labor Market Office at Šv. Dvasios Str: frond, side and back façades, cross section 


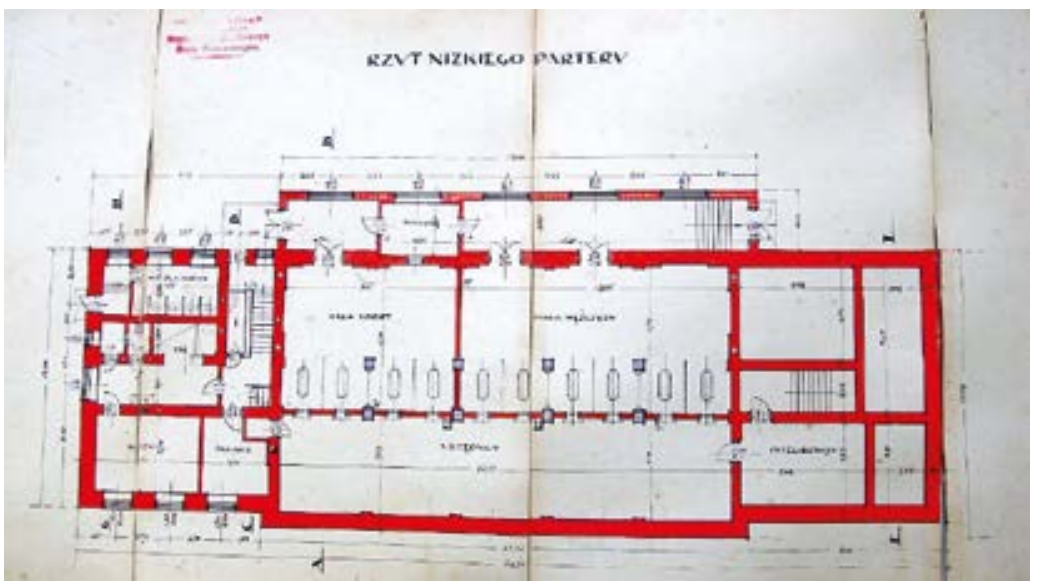

13.

Darbo rinkos pastato Šv. Dvasios g. projektas: pirmo aukšto planas, archit. Jerzis Paprockis, 1930, AAN
Labor Market Office at Šv. Dvasios Str: plan of the ground floor

plano dviejų-trijų aukštų tūris, dengtas keturšlaičiu stogu; modernistinių užuominų teikia tik dideli langai ir asimetriškas jų komponavimo fasaduose būdas [13 il.]. Šioje vietoje projektas, regis, nebuvo realizuotas, ilgainiui institucija jau kaip Darbo, rūpybos ir sveikatos skyrius (Wydział Pracy, Opieki i Zdrowia) veikė Vaivadijos valdyboje tuometinėje Magdalenos gatvėje (dab. Šventaragio g. 3, Vidaus reikalų ministerija).

Šie keli aptartieji projektai buvo suderinti su Viešujų darbų ministerijos tarnybomis (Ministerstwo Robót Publicznych) ir patvirtinti, tačiau nerealizuoti veikiausiai dèl ekonominès krizès, visoje valstybejje „sustingdžiusios" statybinę veiklą, ir dèl to, kad Vilniaus senamiesčio teritorija nebuvo įtraukta ị Vilniaus miesto magistrato Miesto matavimų ir reguliacijos skyriaus (Wydział Pomiarów Miejskich i Regulacji) rengiamą reguliacini Vilniaus miesto planą, ji buvo palikta vaivadijos vyriausiojo konservatoriaus žinioje kaip saugomas senovės paminklas, kurio teritorijoje naujos statybos negalëjo vykti² ${ }^{20}$.

Vienas svarbiausių uždavinių, keltų Lenkijos valstybingumo institucijų kūrime, buvo iždo administravimo organizavimas. Mokestinè sistema, paveldèta iš okupacinès valdžios, egzistavo iki 1925 m., kol įsibėgèjo

20 Rasa Butvilaitė, „Vilnius 1919-1939 metais: naujo architektūrinio tapatumo kūrimas“, in: Acta Academiae Artium Vilnensis, Vilnius, 2019, t. 94: Menas valstybèje, valstybè mene, sud. Lina Michelkevičè, Aušra Trakšelytè, p. 88-89. 

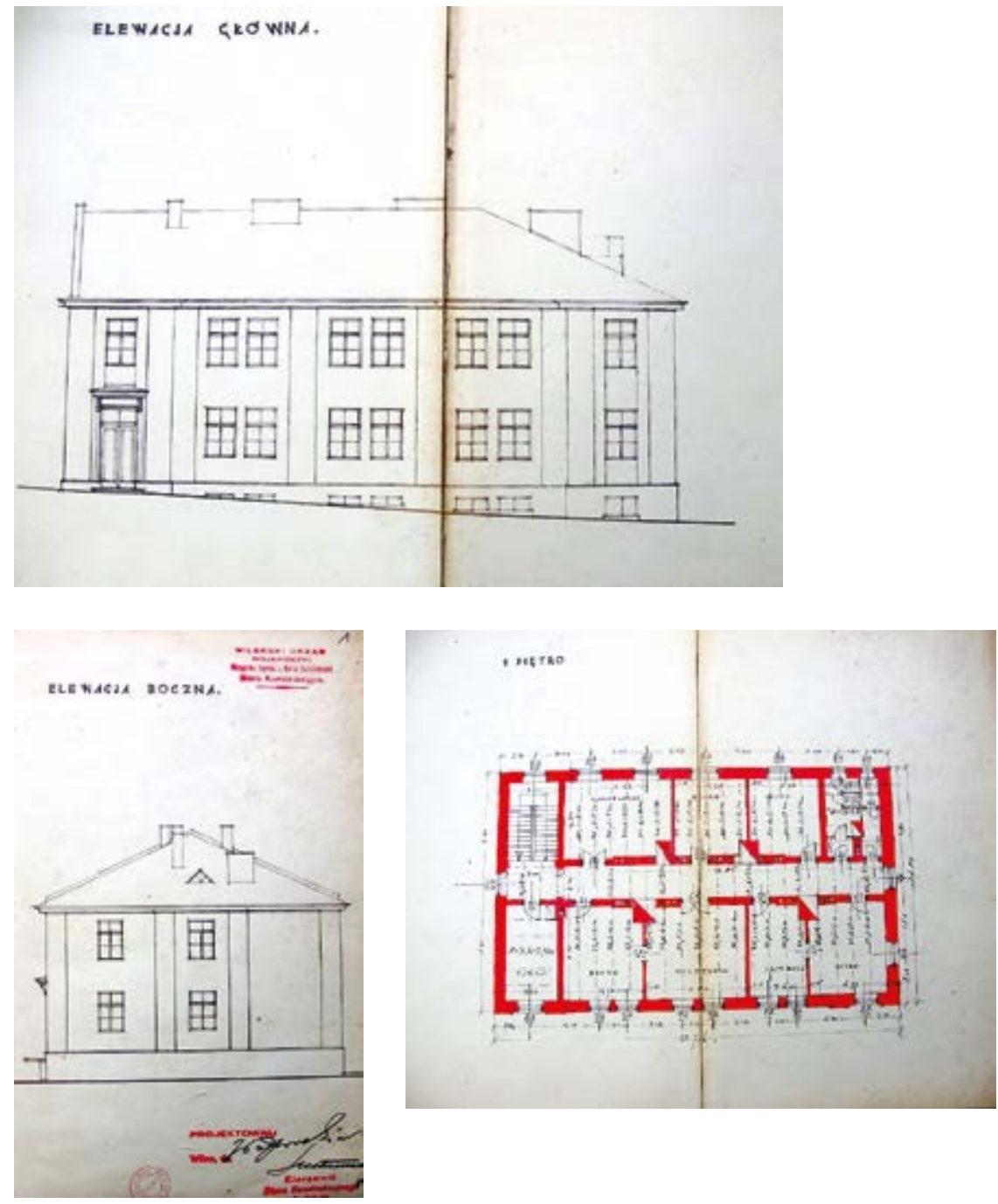

14.

Mokesčių inspekcijos valdybos ir kasų Vingrių g. 6 projektas: pagrindinis ir šoninis fasadai, pirmo aukšto planas, archit. Jerzis Paprockis, 1928, AAN
Tax Inspectorate Board and Treasury Office building project at Vingriu St 6: front and side façades 
1919 m. priimtas mokesčių institucijų ir ịstaigu organizavimo įstatymas ${ }^{21}$, kuriuo suformuotas tripakopis iždo administravimo modelis, sudarytas iš Iždo ministerijos, Iždo rūmų ir jiems pavaldžių mokesčių inspekcijų. Teritorinis iždo administravimo ịstaigų tinklas sutapo su administraciniu valstybės sudalijimu. Vilniuje ịsteigtos Mokesčiu inspekcijos valdybos ir kasu Vingrių g. 6 projektą $1928 \mathrm{~m}$. parengè tas pats J. Paprockis ${ }^{22}$. Tai stačiakampio plano dviaukštis pastatas šlaitiniu stogu; sienų plokštumos pagyvintos suporintais langais ir lizenomis. Skirtingai nei daugelyje kitų Lenkijos vaivadijų, kur naujai statomi šios paskirties objektai išsiskyrė reprezentatyvumu ir modernizuoto klasicizmo formomis (mokesčių inspekcijos Varšuvoje, Balstogejje, Kielcuose, Krokuvoje, Lodzėje, Poznanëje), vilniškis pastatas, sakytumei, kuklios, ganėtinai neišraiškingos architektūros pavyzdys, tačiau tikètina, kad taip architektas apsisprendè siekdamas naują statini priderinti prie šios senojo miesto dalies pastatų mastelio ir vyraujančių nuosaikaus klasicizmo formų [14, 15 il.].

Miesto audinio akcentais dažniausiai tapusių, reprezentacine dvasia alsuojančių administracinės paskirties visuomeninių pastatų šešèlyje telkèsi nepastebima, architektūros požiūriu ne itin vertinga, tačiau vilniečiu kasdienybejje labai svarbių funkcinių-tipologinių grupių architektūra, tenkinusi buitinius, sveikatos ir higienos poreikius.

Atkurtoje Lenkijos valstybėje buvo gana aktyvi valstybinė sveikatos politika. Vykdyta privaloma sanitarinè, epidemiologinè priežiūra ir užkrečiamųu ligu prevencija, taikytas gydymas ir reabilitacija $(1926 \mathrm{~m}$. šioms reikmėms valstybės iždas perėmè net Druskininkų šaltinius ir gydyklas), kurta su tokiomis veiklomis susijusi infrastruktūra. Šiuose procesuose dalyvavo Vidaus reikalų, Darbo ir socialinės globos, Religinių reikalų ir visuomenès švietimo, Komunikacijų ministerijos (Ministerstwo Spraw Wewnętrznych, Ministerstwo Pracy i Opieki Społecznej, Ministerstwo Wyznań Religijnych i Oświecenia Publicznego, Ministerstwo Komunikacji), kuravusios ir ivvairius su sveikatos apsauga susijusius statybinius darbus. Buvo sukurta Sanitarinès ir estetinès krašto išvaizdos būklès pagerinimo

21 Ustawa z dnia 31 lipca 1919 r. o tymczasowej organizacji władz i urzędów skarbowych, in: Dziennik Ustaw, 1919, Nr. 65, poz. 391, [interaktyvus], [žiūrèta 2020-02-03], http://isap.sejm.gov.pl/ isap.nsf/DocDetails.xsp?id=WDU19190650391.

22 Projekt gmachu Urzędu i kasy skarbowej w Wilnie. Umowy, kosztorysy, 1929, in: LCVA, f. 51, ap. 10, b. 1318; Ibid., in: AAN, z. 9: Akta Ministerstwa Spraw Wewnętrznych, sygn. 3819. Šiuo metu pastato tūris pakitęs - jis paaukštintas užstačius trečią aukštą. 

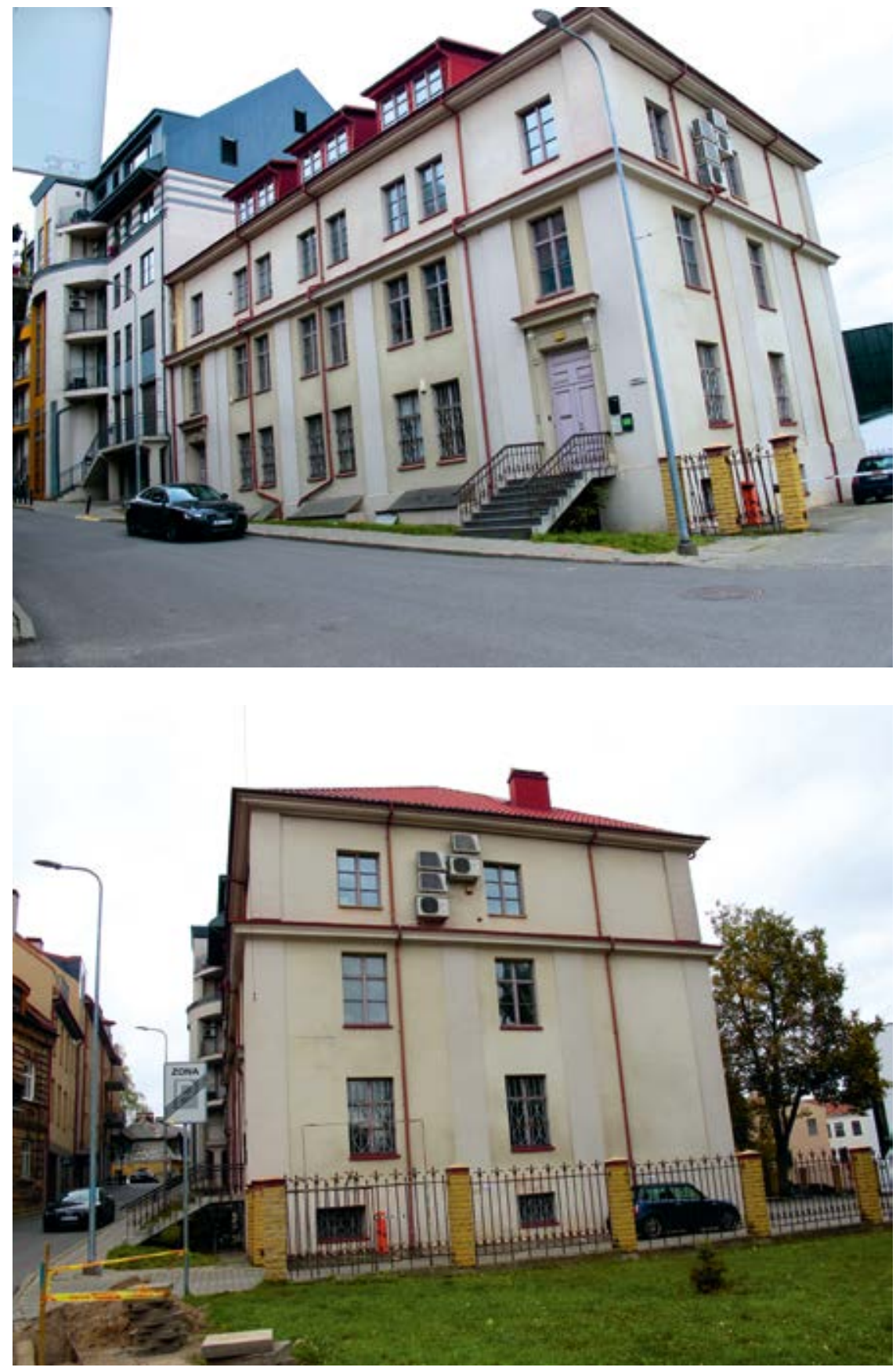

15

Buvusi Mokesčiu inspekcijos valdyba ir kasos Vingrių g. 6: pagrindinis ir šoninis fasadai, Rasos Butvilaitès nuotrauka, 2020
Former Tax Inspectorate Board and Treasury Office building at Vingrių Str 6: front and side façades 


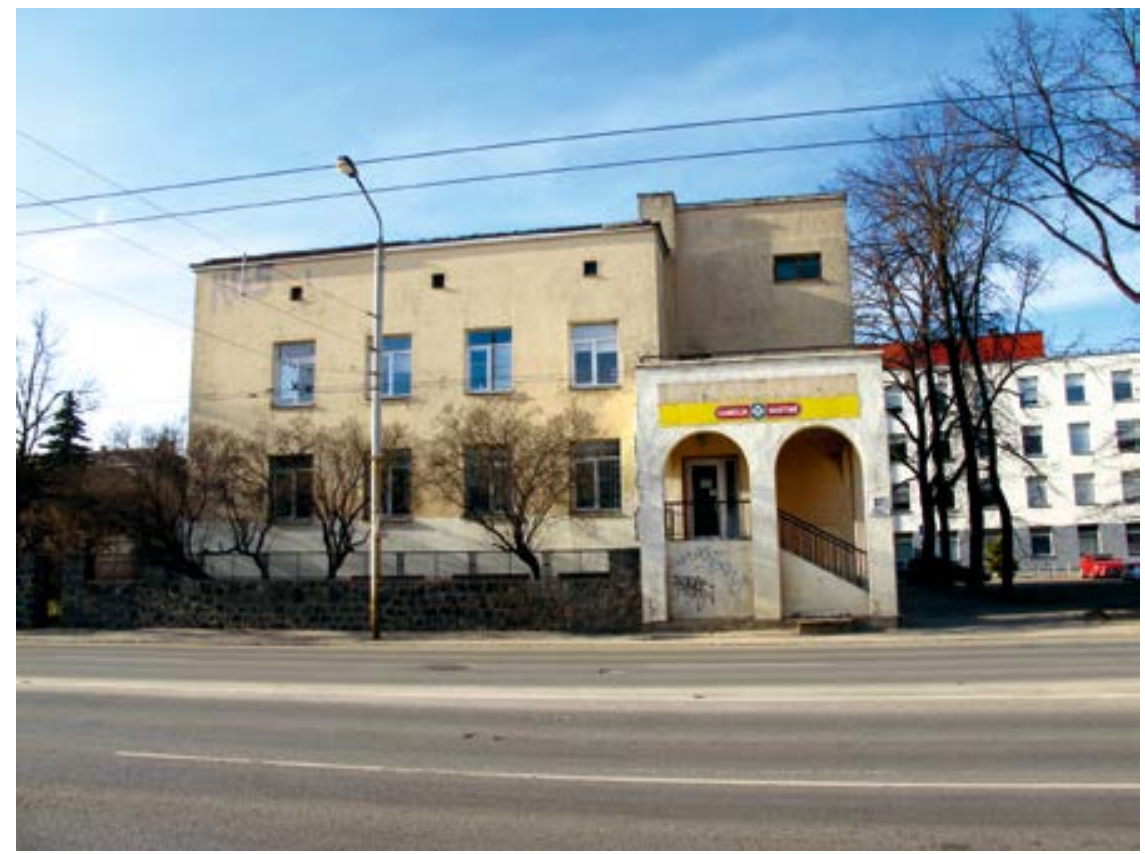

16.

Buvęs Sveikatos centras Kauno g. 37 / Vytenio g. 59, Former Health Center at Kauno Str 37 / Vytenio Str 59 archit. Stefanas Narębskis, inž. Władysławas Adolpfas, 1930-1932, Rasos Butvilaitès nuotrauka, 2019

darbu programa (Program pracy nad podniesieniem stanu sanitarnego i estetycznego wyglądu kraju) - akivaizdu, kad sveikatos, higienos reikalai glaudžiai sieti su estetinėmis urbanistinès aplinkos kokybėmis (XX a. 3 deš. atliekant inspektavimą, nuolat konstatuota, kad Vilniaus sanitarinè būklè ir miesto tvarka - apgailètina). Vidaus reikalų ministerijos Sveikatos tarnybos departamentas parengè rekomendacinę Sveikatos centro (Osrodek zdrowia) programą, projektą ir sąmatą, pagal kurią tokiame pastate turẻjo būti ir sanitarinès priežiūros, ir gydytojų, ir skubaus stacionaro patalpos ${ }^{23}$. Iki šių dienų mažai pakito buvęs Sveikatos centras Kauno g. 37 / Vytenio g. 59 (archit. Stefanas Narębskis, inž. Władysławas Adolphas, 1930-1932)24 - mažaaukštis, kompaktiško skaidyto tūrio, su plokščiu stogu, fasadu estetika lakoniška ir taupi. Pastato architektūroje akivaizdi subtili tradicionalizmo ir avangardinio modernizmo dermè [16 il.].

23 Stan sanitarny osiedli: Wojewodstwo Wileńskie, 1927-1931, in: AAN, z. 15: Ministerstwo Opieki Społecznej, sygn. 871; Księga sanitarna woj. Wileńskiego za 1938 r., in: AAN, z. Ministerstwo Opieki Społecznej, sygn. 824.

24 Narębski Stefan, Ośrodek zdrowia, in: Muzeum Architektury we Wrocławiu, MAt IIIb-500. 

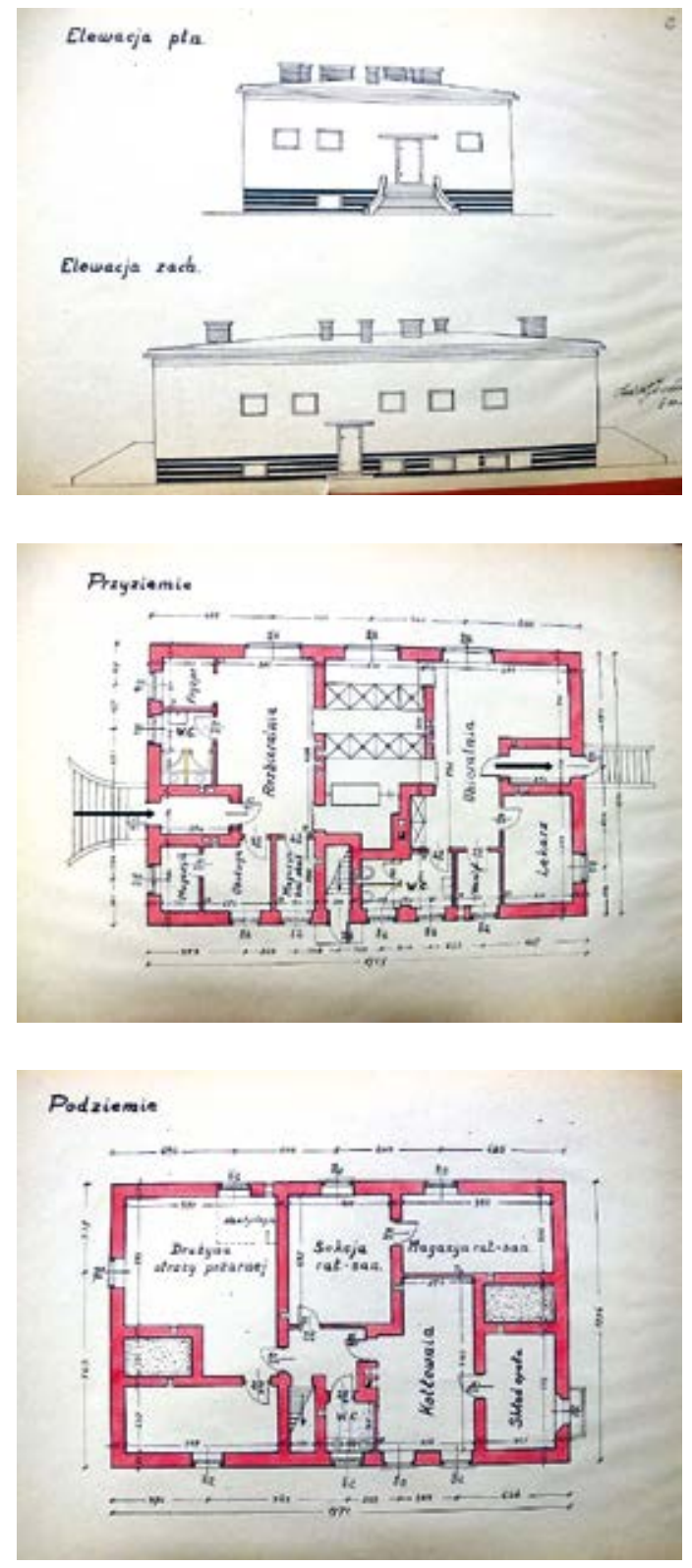

17.

Dezinfekcinių maudyklų Mindaugo g. projektas: fasadai, 1939, AAN

Project of Disinfection baths at Mindaugo Str.: façades

18.

Dezinfekcinių maudyklų Mindaugo g. projektas: pirmo aukšto planas, 1939, AAN

Project of Disinfection baths at Mindaugo Str:: plan of ground floor

19.

Dezinfekcinių maudyklų Mindaugo g. projektas: pusrūsio planas, 1939, AAN

Project of Disinfection baths at Mindaugo Str:: plan of basement 


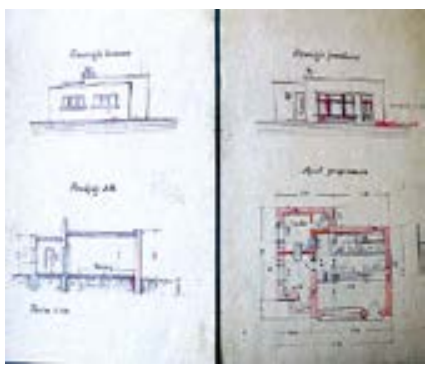

20.

Žuvies parduotuvių Kalvarijų turguje projektas, inž. Tadeuszas Jasińskis, 1935, LCVA

Project of fish shops at Kalvarijų Market

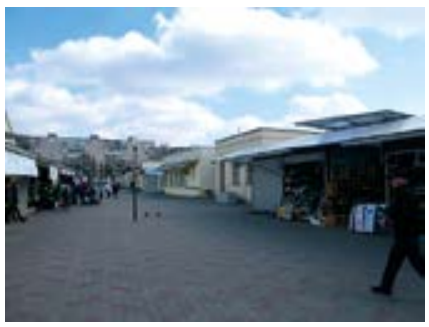

22.

Paviljonai Kalvarijų turguje, Rasos Butvilaitès nuotrauka, 2019

Pavilions at the Kalvarijų Market

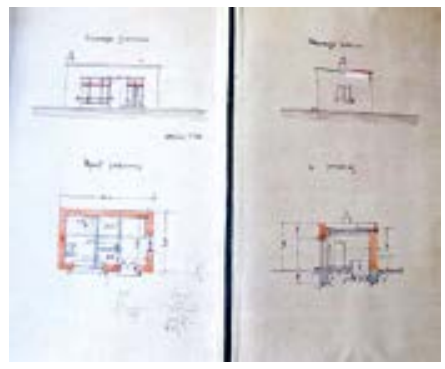

21.

Žuvies parduotuviu Stepono turguje projektas, inž. Tadeuszas Jasińskis, 1936, LCVA

Project of fish shops at Stephens Market

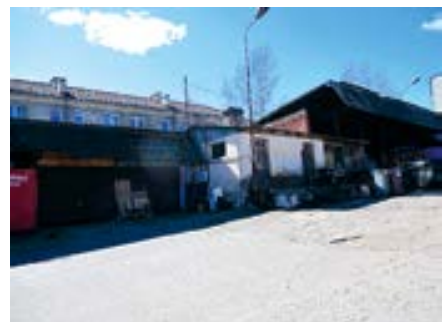

23.

Paviljonų liekanos buvusiame Stepono turguje, Rasos Butvilaitès nuotrauka, 2019

Remains of pavilions at the former Stephen's Market

Dezinfekcinės maudyklos buvo visuomeninès sveikatos apsaugos sistemos dalis. Jos buvo įrengiamos viešosiose pirtyse, masinio susibūrimo vietose - mokyklose, ligoninėse ir sveikatos centruose. Maudyklų ,programą“ sudarè trys praėjimais atskirtos dalys: pirmasis buvo nusirengimo kambarys (čia buvo paliekami nešvarūs drabužiai), antrasis buvo skirtas žaizdoms dezinfekuoti ir gydytis bei praustis dušuose, trečiasis - apsirengti. Pastate buvo ịrengta ir drabužių dezinfekavimo patalpa. Tokios paskirties objekto pavyzdys - dezinfekcinių maudyklų Mindaugo g. 1939 m. projek$\operatorname{tas}^{25}[17-19$ il.]. sygn. 3824. 
Antisanitarijos židiniais laikyti turgūs, todèl rūpintasi sukurti higienos reikalavimus atitinkančią infrastruktūrą. Kalvarijų, Medienos, Stepono turguose inžinieriaus Tadeuszo Jasińskio buvo suprojektuoti ir kai kur įrengti žuvies paviljonai su vandentiekiu, šaldytuvais ir rezervuarais gyvai žuviaii ${ }^{26}$ [20, 21 il.]. Tai - kompaktiškų tūrių ir utilitarinės „mažakalbès“ modernistinès architektūros pavyzdžiai. Projektai buvo realizuoti (išskyrus Medienos turgu, buvusi tarp Pylimo ir Naugarduko gatvių, dabar toje vietoje - skveras), tačiau Kalvarijų turguje, vykdant atnaujinimo darbus XX a. 6 deš., jų išvaizda gerokai pakito, o buvusio Stepono turgaus vietoje šiuo metu yra gamybinès patalpos, sandèliai, taigi tarpukario statiniai „ištirpo“ priestatų ir antstatų gausoje [22, 23 il.].

Kaip viena iš sveikatinimo rūšių aktyviai propaguotas sportas. Nuo 1927 m. fizinị lavinimą ir karinị rengimą skatino ir rėmė valstybė. Vilniuje įkurtas viso Šiaurès rytų regiono sporto centras „Wilno“. Militarizuotame Vilniuje sporto sklaidos kampaniją inicijavo kariškiai, sudarę nemažą miesto gyventoju dali. Sportas laisvalaikio metu turèjo „pagerinti karių fizinị pasirengimą ir pakelti nuotaiką“, - tą nuolat pabrèžè valstybės vadovas Józefas Pilsudskis. Atviri sporto aikštynai kariuomenės pastangomis gana nesudètingai buvo ịrengti daugelyje Vilniaus vietų. Tuo tarpu išteklių ir infrastruktūros požiūriu anuomet bemaž didžiausias iššūkis buvo baseino, simbolizavusio modernaus gyvenimo standartus, statybos. Vilniaus miesto taryba, išklausiusi Vaivadijos fizinio lavinimo ir karinio rengimo komiteto sekretoriaus kapitono Kawalco ir inžinieriaus Miecznikowskio argumentus, 1928 m. gegužès 29 d. prièmè sprendimą Rinktinès g. 2, netoli elektrinės ir kareivinių, buvusių žydų kapinių teritorijoje, skirti 5230 kv. m plotą baseino su ,visais higienos įrenginiais ir pirtimis“ statybai; visiškai pritarta jo projekto autoriaus, minèto Miecznikowskio, siūlymui, kad „,baseinas būtų viešas ir visuotinis, prieinamas visiems žmonių sluoksniams, neišskiriant jokių visuomenės ir tautinių grupių“27. $1933 \mathrm{~m}$. lapkričio $7 \mathrm{~d}$. Vilniaus miesto prezidentas ir Vilniaus gynybinių ịtvirtinimų vadas pasirašė baseino statybų ketinimų protokolą, tačiau dèl ekonominès krizės padarinių jis taip ir nebuvo realizuotas - sumanymas atgimè ir buvo materializuotas tik XX a. 7 dešimtmetyje.

26 Žuvies parduotuvių projektai Kalvarijų, Medienos ir Stepono turgavietėse, 1935-1936, inž. Tadeusz Jasiński, in: LCVA, f. 64, ap. 8, b. 348.

27 Vilniaus miesto magistrato dokumentai, 1933, in: LCVA, f. 64, ap. 9, b. 2531, 1. 1-2. 


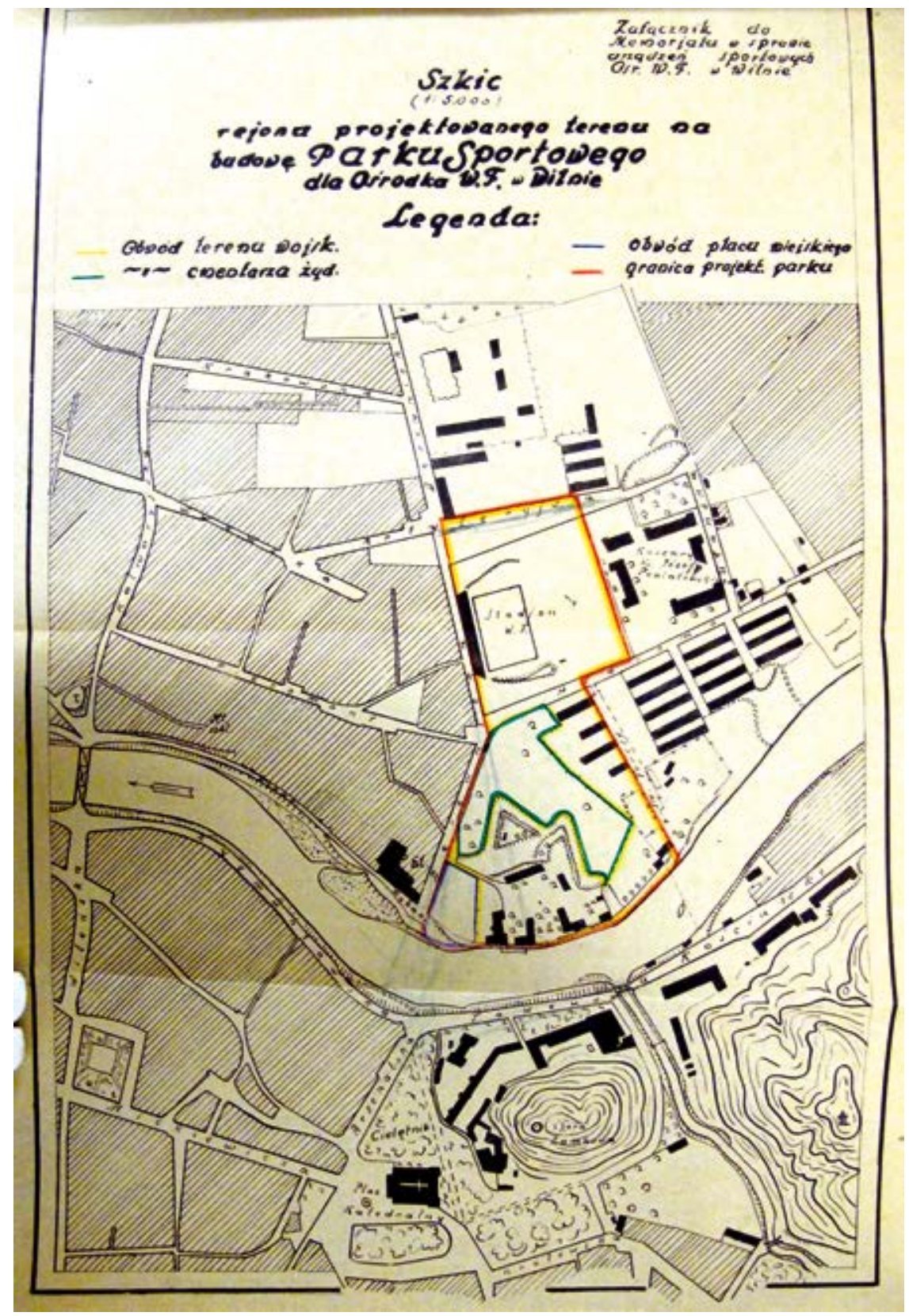

24.

Teritorijos, skirtos Sporto parkui Piromonte, projekto eskizas, 1933, LCVA
Sketch of the project for the territory for the Sports Park in Piromont (Vilnius) 
1933 m. gruodžio 12 d. Vilniaus gynybinių ittvirtinimų vadovybė paskelbė ir pateikè miesto magistratui vykdyti Fizinio lavinimo ir karinio rengimo priemonių suformavimo memorialą, kuriuo numatyta Vilijos krantinėje Piromonte kurti Sporto parką ${ }^{28}$ [24 il.]. Vieta pasirinkta neatsitiktinai: visai šalia miesto centras, kurị tereikia tiltu (jo statybos jau buvo numatytos) sujungti su Piromontu, be to, ji ,estetiniu požiūriu graži - su vaizdais i upę, Pilies ir Triju kryžių kalnus, palankios gamtinės sveikatinančios ir techninės sąlygos; gruntas sausas, žvyringas, gerai sugeriantis drėgmę “29. Projektuojamą Sporto parką planuota pritaikyti žiemos ir vasaros sporto šakoms, įrengti uždaras ir atviras erdves: lengvosios atletikos aikštynus, teniso kortus, dviračių ir motosporto trekus, dideli funkcinėmis zonomis suskirstytą sodą, ledo ritulio aikštę, rogučių kalnelius ir žiemos žaidimų aikšteles vaikams, gimnastikos aikštę moterims, paplūdimị ir vietas irkluotojams bei plaukikams, net tris baseinus (atvirą ir uždarą plaukimo bei uždarą irklavimo), pastatyti tribūnas, gimnastikos ir treniruočių sales su persirengimo kambariais ir dušinėmis, administracinị pastatą su medicinos punktu ir poilsio kambariais ir kita. Taigi užsimota plačiai, sumanymas iš tiesų buvo modernus dèl urbanistinio ịžvalgumo, daugiafunkciškumo ir sudètingos infrastruktūros, siekimo orientuotis ị miestiečių gerovès kūrimą.

Atskiri kariuomenès padaliniai, dislokuoti Vilniuje, steigè savo sporto klubus, rengè tarpusavio varžybas ir kiekvieno jų ambicija buvo ikurti sporto (visu pirma futbolo) aikštyną. Parengti tokio aikštyno pavyzdinị projektą buvo ịpareigotas vyresnysis leitenantas (lenk. porucznik) Bolesławas Waligóra, Vilniaus pėstininkų pulko kultūros ir švietimo reikalų referentas. Jis laikomas tuometinių stadionu Vilniuje autoriumi. Norèta irrengti reprezentacinị stadioną ant Tauro kalno, bet galiausiai jis rado vietą Piromonte (Rinktinès g.) ir $1929 \mathrm{~m}$. birželio $6 \mathrm{~d}$. buvo iškilmingai atidarytas (sovietmečiu transformuotas i „̇̌algirio“ stadioną). 1929 m. čia vyko Tarptautinès lengvosios atletikos varžybos.

Naujasis stadionas atrodo ịspūdingai. Bėgimo takai ir šuoliụ ị tolị aikštelès nusipelno ypatingų pagyrų. Stadionas turi 420 metrų šešiu takeliu greičio ruožą, futbolo

28 Vilniaus miesto magistrato dokumentai, 1933, in: LCVA, f. 64, ap. 9, b. 2531, lapai nenumeruoti. 


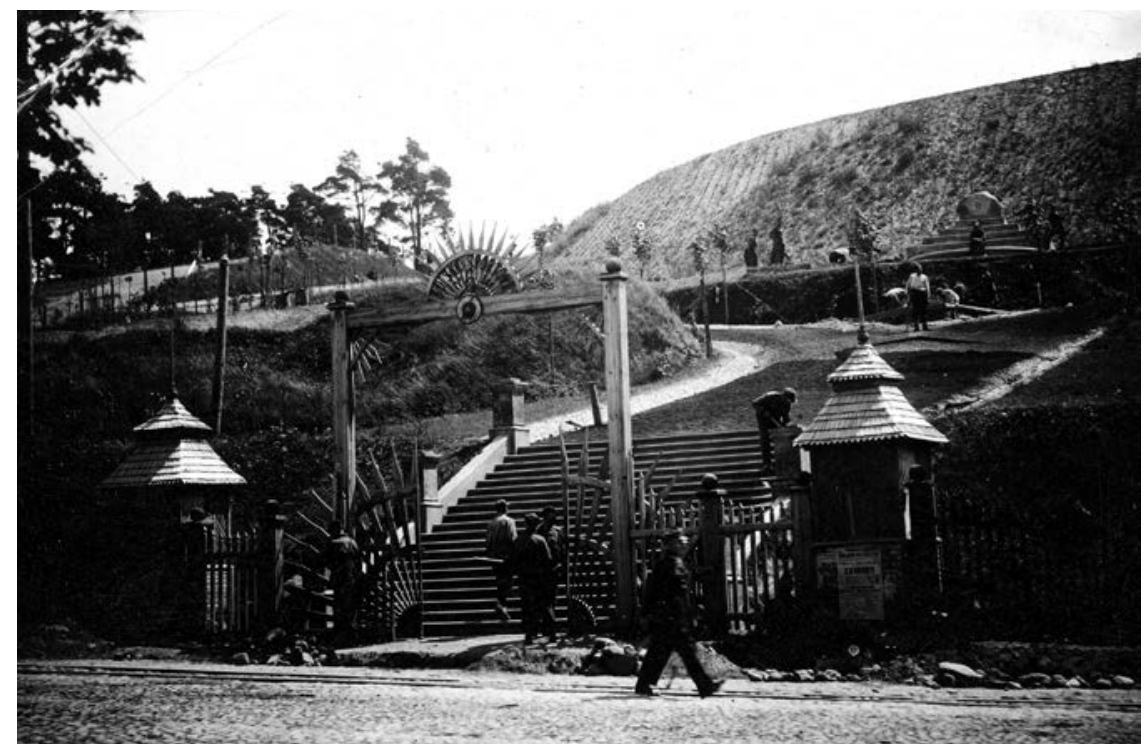

25.

Pagrindinis įejimas į sporto aikštyną Kalnų parke, 1926, NAC
The main entrance to the sports field in Hills Park in Vilnius

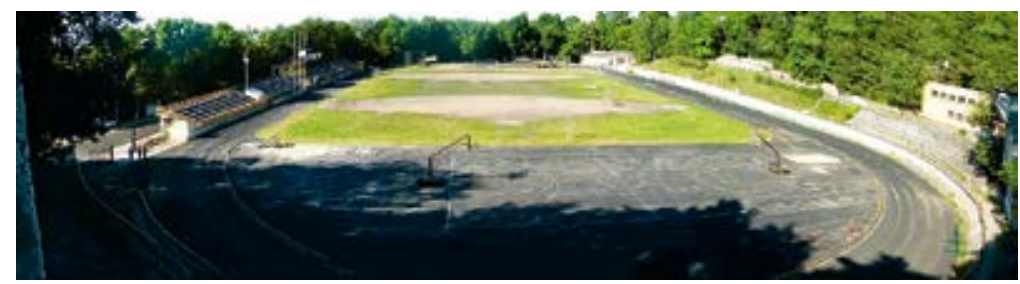

26.

Kalnų parko sporto aikštyno bendras vaizdas XXI a. 1 deš.
A general view of the Hills Park sports field in the first decade of the 21 st century 


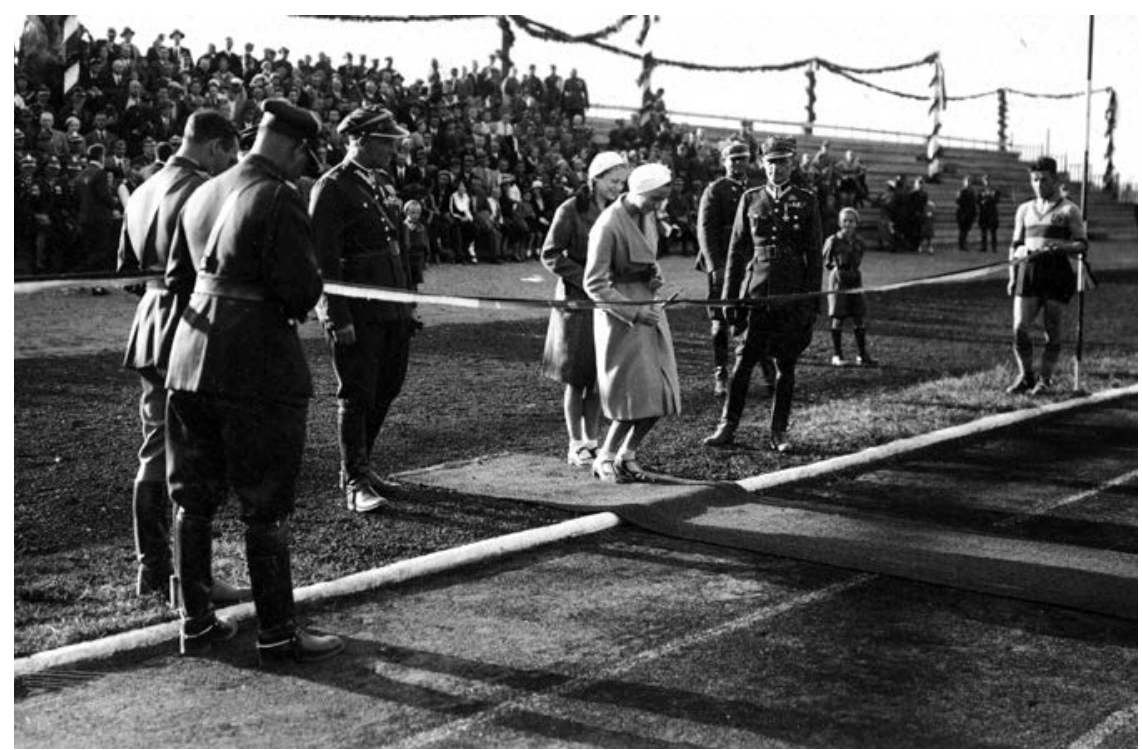

27.

Wanda ir Jadwiga Piłsudskos stadiono atidarymo iškilmėse, Jarosławo Niecieckio nuotrauka, 1933, NAC

Wanda and Jadwiga Piłsudski at the opening ceremony of the Stadium in Vilnius

aikštę, teniso kortus, sporto aikšteles, apžvalgos bokštus, taip pat nebaigtą dviračių taką ir didžiulę tribūną. ${ }^{30}$

Moderniai ịrengtas, funkcionalistinės ir konstruktyvistinės architektūros formomis (jos priskiriamos Romualdo Gutto ir Stanisławo Bukowskio autorystei ${ }^{31}$ ) įvaizdintas Antrojoje Lenkijos Respublikoje tai buvo vienas didžiausių stadionų. Daugmaž tuo metu ịrengtas ir Kalnų parko (sovietmečiu - „Dinamo“) sporto aikštynas ${ }^{32}$ [25, 26 il.], greta kareivinių Verkių gatvėje $1933 \mathrm{~m}$. vartus atvėrè Maršalo J. Pilsudskio stadionas (Stadion sportowy im. marszałka Józefa Piłsudskiego w Wilnie, dabar teritorija užstatyta, ją kerta Ulonų g.) [27 il.]. Šie sporto aikštynai buvo nemenkos vilniečių dalies traukos židiniai ir laisvalaikio praleidimo vietos; jie buvo svarbūs ir sociourbanistiniu požiūriu - formavo rekreacines miesto salas centrinèje dalyje ir kiek atokesnèse vietose.

30 Waldemar Wołkanowski, „Zanim zniknie „Žalgiris“, czyli jak powstawał stadion w Wilnie“, 2017, [interaktyvus], [žiūrèta 2020-05-17], http://www.wilnoteka.lt/artykul/zanim-znikniequotzalgirisquot-czyli-jak-powstawal-stadion-w-.

31 Žr. Sebastiano Wicherio straipsnị šiame leidinyje.

32 NAC, Zespół: Koncern Ilustrowany Kurier Codzienny - Archiwum Ilustracji, Sygn. 1-S-89. 
Tarpukariu Vilniaus visuomeninès architektūros funkcinę-tipologinę ìvairovę ir raidą apsprendè valstybès institucijų raida, atsikūrusios valstybės siekis kurti XX a. pažangą atliepiančią infrastruktūrą, turinčią užtikrinti modernios visuomenès gerovę. Sudètinga geopolitinè Vilniaus krašto situacija lèmè ūkinio gyvenimo komplikacijas, dèl kurių savo ruožtu ir statybinè veikla neturèjo tokių investicinių išteklių kaip kituose Antrosios Lenkijos Respublikos regionuose. Todèl Vilniaus, nors ir vaivadijos centro, architektūra tarpukariu plètojosi laipsniškai ir savo dinamiškumu bei gausa neprilygo didžiosioms Lenkijos vaivadijoms, tačiau pirmavo moderniu požiūriu ị urbanistinį naujų statybų kontekstualumą. Aptariamuoju laikotarpiu Vilniuje daugiausia statyti pakankamai retrospektyvių formų pastatai projektuotojų sumanymu turejjo organiškai ịsilieti ị didinga istorija alsuojančio miesto istorinių stilių panoramą, o raiškūs modernizmo pavyzdžiai - suteikti Vilniui atsikūrusios modernios valstybės tapatumo ženklus. Visuomeninès architektūros pavidaluose akivaizdi savotiško istoristinio vietos, nacionalinę dvasią reflektuojančio ,stiliaus“ ir modernizmo pavidalų ìvairovės dermė. Funkcinė ir architektūrinė pastatų ịvairovė, jų lokalizacija miestovaizdyje davė svarbų impulsą tolesnei, jau sovietinio miesto raidai.

Gauta 20200302 


\section{Šaltiniai}

Akta w sprawie budowy Sądu Grodzkiego w Wilnie, r. 1928-1930, in: LCVA, f. 51, ap. 10, b. 1296 (lapai nenumeruoti).

Dekret o najwyższej Izbie Kontroli Państwa, Dziennik Ustaw, 1919, Nr. 14, poz. 183 [interaktyvus], [žiūrèta 2020-01-12], http://isap. sejm.gov.pl/isap.nsf/DocDetails.xsp?id=WDU19190140183.

Kosztorys na roboty Sądu Grodzkiego w Wilnie, 1928, in: LCVA, f. 51, ap. 10, b. 1306.

Księga sanitarna woj. Wileńskiego za 1938 r., in: AAN, z. Ministerstwo Opieki Społecznej, sygn. 824.

Lachert Bohdan, Szanajca Józef, Winkler W., Szkoły Handlowe w Wilnie, 1939 r., in: Muzeum Architektury we Wrocławiu, MAt IIIb-680/1-4, MAt IIIb-219/P, MAt IIIb266/1-19/P.

NAC, Zespół: Koncern Ilustrowany Kurier Codzienny - Archiwum Ilustracji, Sygn. 1-S-89.

Narębski Stefan, Ośrodek zdrowia, in: Muzeum Architektury we Wrocławiu, MAt IIIb-500.

Pašto ir telegrafo direkcijos Vilniuje projektas, [nedatuotas], inž. archit. Julianas Putermanas, in: AAN, z. Akta Ministerstwa Spraw Wewnętrznych, sygn. 3823.

Projekt gmachu dyrekcji Lasów Państwowych w Wilnie, 1930 r., in: LCVA, f. 51, ap. 10, b. 1301 .

Projekt gmachu dyrekcji Lasów Państwowych w Wilnie, in: AAN, z. 9: Ministerstwo Spraw Wewnętrznych, sygn. 3817.

Projekt gmachu Giełdy pracy, 1930 r., in: AAN, z. 9: Akta Ministerstwa Spraw Wewnętrznych, sygn. 3821 .

Projekt gmachu Giełdy pracy, 1930 r., in: LCVA, f. 51, ap. 10, b. 1316.

Projekt gmachu Urzędu i kasy skarbowej w Wilnie, in: AAN, z. 9: Akta Ministerstwa Spraw Wewnętrznych, sygn. 3819.

Projekt gmachu Urzędu i kasy skarbowej w Wilnie. Umowy, koszorysy, 1929, in: LCVA, f. 51, ap. 10, b. 1318 .
Projekt kąpieliska odkażającego, in: AAN, z. 9: Ministerstwo Spraw Wewnętrznych, sygn. 3824.

Projekt przebudowy Pałacu poTyszkiewiczowskiego $\mathrm{w}$ Wilnie na gmach bibliotek publicznych, 1928, in: AAN, z. 9: Ministerstwo Spraw Wewnętrznych, sygn. 3816.

Projekt Sądu Grodzkiego w Wilnie, archit. Jerzy Paprocki, 1928, in: LCVA, f. 51, ap. 10, b. 1300 .

Projekt Urzędu Poczt i Telegrafow, in: AAN, z. 9: Akta Ministerstwa Spraw Wewnętrznych, sygn. 3823.

Rozporządzenie Prezydenta Rzeczypospolitej z dnia 28 czerwca 1924 r. o statucie przedsiębiorstwa „Polskie Lasy Państwowe“, Dz. U. z 1924 r., Nr. 56, poz. 570, [interaktyvus], [žiūrèta 2020-01-14], http://isap.sejm. gov.pl/isap.nsf/DocDetails.xsp?id=WDU19240560570.

Sprawa biblioteki im. Wróblewskich w Wilnie, 1931 r., in: AAN, z. 9: Ministerstwo Spraw Wewnętrznych, sygn. 3815.

Stan sanitarny osiedli: Wojewodstwo Wileńskie, 1927-1931, in: AAN, z. 15: Ministerstwo Opieki Społecznej, sygn. 871.

Ustawa z dnia 16 marca 1933 r. o Funduszu Pracy, Dz. U. 1933, Nr. 22, poz. 163, [interaktyvus], [žiūrèta 2020-02-01], http:/isap. sejm.gov.pl/isap.nsf/DocDetails.xsp?id=WDU19330220163.

Ustawa z dnia 3 czerwca 1921 r. o Kontroli Państwowej, Dziennik Ustaw, 1921, Nr. 51, poz. 314, [interaktyvus], [žiūrèta 2020-0204], http://isap.sejm.gov.pl/isap.nsf/DocDetails.xsp?id=WDU19210510314.

Ustawa z dnia 31 lipca 1919 r. o tymczasowej organizacji władz i urzędów skarbowych, Dziennik Ustaw, 1919, Nr. 65, poz. 391, [interaktyvus], [žiūrèta 2020-02-03], http:// isap.sejm.gov.pl/isap.nsf/DocDetails.xsp?id=WDU19190650391.

Utworzenie okręgowej izby Kontroli Państwowej w Wilnie, 1922, Dziennik Ustaw, Nr. 51, poz. 314, [interaktyvus], [žiūrèta 2020-0111], https://www.prawo.pl/akty/dz-u-192275-684,16879789.html. 
Vilniaus miesto magistrato dokumentai, 1933, in: LCVA, f. 64, ap. 9, b. 2531.

Žuvies parduotuvių projektai Kalvarijų, Medienos ir Stepono turgavietėse, 1935-1936, inž. Tadeusz Jasiński, in: LCVA, f. 64, ap. 8, b. 348 .

\section{Literatūra}

Antanavičiūtė Rasa, Menas ir politika Vilniaus viešosiose erdvèse, Vilnius: Lapas, 2019.

Butvilaitė Rasa, „Vilnius 1919-1939 metais: naujo architektūrinio tapatumo kūrimas“, in: Acta Academiae Artium Vilnensis, Vilnius, 2019, t. 94: Menas valstybejje, valstybè mene, sud. Lina Michelkevičè, Aušra Trakšelytè, p. 84-119.

Dolistowska Małgorzata, „,Miłe miasto“ między tradycją a awangardą: architektura Wilna w dwudziestoleciu międzywojennym: zarys problematyki“, in: Stan badań nad wielokulturowym dziedzictwem dawnej Rzeczypospolitej, t. 8, Białystok: Instytut Badań nad Dziedzictwem Kulturowym Europy, 2017, p. 87-149.

Konkursy architektoniczne w Polsce w latach 1918-1939, Wrocław: Muzeum Architektury i Odbudowy, 1970.

Kučiauskas Karolis, Prieškario Vilniaus urbanistinis modelis ir jo recepcija karo ir pokario metais (1932-1956 m.), [Rankraštis]: Daktaro disertacija, Vilnius: Vilniaus universitetas, 2016.

Leśniakowska Marta, Architektura w Warszawie. Lata 1989-2001, Warszawa: Arkada, 2002.

Lukšionytė-Tolvaišienė Nijolè, Istorizmas ir modernas Vilniaus architektūroje: Monografija, in: Acta Academiae Artium Vilnensis, t. 18, Vilnius: Vilniaus dailès akademijos leidykla, 2000.

Małachowicz Edmund, „Architektura dwudziestolecia międzywojennego w Wilnie“, in: Studia i materiaty do teorii $i$ historii architektury i urbanistyki, t. XVII: Architektura $i$ urbanistyka $w$ Polsce $w$ latach 1918-1978, Warszawa, 1989, p. 121-141.
Markevičienè Jūratè, „Nuo šiuolaikinio miesto iki sostinès: urbanistinio Vilniaus įvaizdžio kaita 1936-1939 ir 1939-1940 m.“, in: Sostine kaip tapatumo simbolis: Vilnius ir Kaunas tarpukario kultūroje, Vilnius: LLTI, 2014.

(Ne)matomas Vilnius: tarpukario dailes ir architektūros pavidalai: Parodos Vytauto Kasiulio dailès muziejuje (2018 0612 - 2018 09 16) katalogas, sudarytojos ir tekstu autorès Algè Andriulytè, Rasa Butvilaitè, Ilona Mažeikienė, Vilnius: Vilniaus dailès akademijos leidykla, 2018.

Poklewski Józef, Polskie życie artystyczne w międzywojennym Wilnie, Torun: Wydawnictwo UMK, 1994, p. 170-196.

Pszczółkowski Michał, Architektura użyteczności publicznej II Rzeczypospolitej 1918-1939, Łódź: Dom Wydawniczy Księży Młyn, 2014.

Pszczółkowski Michał, Kresy nowoczesne. Architektura na ziemiach wschodnich II „Rządowa tandeta budowlana“, in: Dziennik Wileński, 192924 (VI).

Rzeczypospolitej 1921-1939, Łódź: Dom Wydawniczy Księży Młyn, 2016.

Stefan Narębski (1892-1966) - architekt, konserwator, profesor: Katalog towarzyszy wystawie, autor katalogu Michał Pszczółkowski, Toruń: Muzeum Okręgowie w Toruniu, 2017.

Vilnius, 1900-2016: architektūros gidas, sud. Marija Drėmaitè, Rūta Leitanaitè, Julija Reklaitè, Vilnius: Lapas, 2016.

Wicher Sebastian, Żyć architektura. Życie i twórczość Stanistawa Bukowskiego (1904-1979), Białystok: Stowarzyszenie Architektów Polskich Oddział w Białymstoku, Studio Wydawnicze UNIKAT, 2009.

Wołkanowski Waldemar, „Zanim zniknie „Žalgiris“, czyli jak powstawał stadion w Wilnie“, 2017, [interaktyvus], [žiūrèta 2020-05-17], http://www.wilnoteka.lt/artykul/zanim-zniknie-quotzalgirisquot-czyli-jak-powstawal-stadion-w-wilnie.

„Zabytkowa dzielnica miasta Wilna“, in: Kurjer Wileński, 193606 26, Nr. 174 (3775), p. 9. 


\section{Santrumpos}

AAN - Archiwum Akt Nowych (Naujujų aktų archyvas), Varšuva

LCVA - Lietuvos centrinis valstybės archyvas

NAC - Narodowe Archiwum Cyfrowe (Nacionalinis skaitmeninis archyvas), Varšuva 


\title{
Summary
}

\section{Public Buildings in Interwar Vilnius: The Diversity of Institutions, Functions and Architecture $^{1}$}

\author{
Rasa Butvilaitè
}

Keywords: architecture of Vilnius, modernism, Warsaw school of modernism, public architecture.

After the re-establishment of independence in 1918 in Poland the process of forming new administrative structures, eliminating the effects of the WWI and modernising the State's cultural and economic life began, and was followed by the intense construction of building. Vilnius was annexed and acquired the voivodship centre status. In 1919-1939, in many other Polish cities, new institutions of local government, banking, science and education, health, social insurance, communication, transport and culture were established. The variety of functional needs led to the wide variety of architectural forms of that period and the appearance of heterogeneous architecture. Institutional decisions aimed to prudently preserve the Old Town of Vilnius, to revitalise its monuments, and the new buildings of modernised traditionalism and pure modernism just outside the old city (especially in the New Town) counterbalanced the Tsarist architectural image of the city and formed new guidelines for urban development and architectural landscape in many urban areas. Previous buildings were often adapted and used for the new administrative purposes (e. g. a new wing was added to the 19 th century courthouse on Gediminas avenue in 1929 etc.). The emergence of new buildings (especially after 1935, when the state economy started to recover after the crisis and a wave of construction flooded into Vilnius) testified to the efficiency and modernity of the powers and institutions of the Second Polish Republic in the Vilnius region (e.g. Postal Savings Bank, Polish Land Bank, Public Insurance Company etc.). Many new public architecture projects were not implemented and remained only as

1 This research was funded by a grant (No. S-MOD-17-12) from the Research Council of Lithuania. 
drawings (e. g. Trade school building complex, palaces of the State Forest Directorate and Labor market, Secondary school at Subačius st., etc). During the Interwar period, the architecture of Vilnius developed gradually, and its dynamism and abundance did not match capitals of the great voivodeships of Poland (Warsaw, Poznan, Krakow, Legnica, Włocławek, Gdynia). However, the harmony of the buildings with their surroundings / context, volumes and spaces, specific architectural solutions, elements and finishing materials determines the unique character of modernist architecture, which only appeared in Interwar Vilnius. 